\title{
İmam Hatip Okulları Kur'an-ı Kerim Dersi Öğretim Programlarında Yer Alan Yöntem ve Tekniklerin Değerlendirilmesi (1924-2016)
}

\begin{abstract}
An Assessment on Methods and Techniques in the Curricula of the Course of Quran for Imam Hatip High Schools (1924-2016)
\end{abstract}

\author{
Nazif YILMAZ, Sorumlu Yazar, Doktora Öğrencisi. \\ Millî Eğitim Bakanlığı, Din Öğretimi Genel Müdürlüğü, Ankara/Türkiye. \\ nazifyilmaz@gmail.com \\ https://orcid.org/0000-0003-4701-5763
}

ISSN: 1303-880X

e-ISSN: 2667-7504

http://ded.dem.org.tr

Makale Türü / Article Type:

Araştırma Makalesi / Research Article

Geliş Tarihi / Received Date: 26.10.2020

Kabul Tarihi / Accepted Date: 09.12.2020

Yayın Tarihi / Published Date: 25.06.2021

Tr/En: $\operatorname{Tr}$

Intihal / Plagiarism: Bu makale, en az iki hakem tarafindan incelendi ve intihal içermediği teyit edildi. / This article has been reviewed by at least two referees and scanned via a plagiarism software.

Attf/Citation: Yılmaz, N. (2021). İmam hatip okulları Kur'an-1 Kerim dersi öğretim programlarında yer alan yöntem ve tekniklerin değerlendirilmesi (1924-2016).. Değerler Eğitimi Dergisi, 19 (41), s.129-169.

https://doi.org/10.34234/10.34234/ded.816323 
Öz: İmam hatip liseleri mezunlarının mesleki yeterliliklerinin imamlık, hatiplik ve Kur'an Kursu öğreticiliği yapacak düzeyde olması beklenmektedir. Ayrıca İlahiyat/İslami İlimler Fakültelerini tercih eden/edecek öğrenciler için iyi bir Kur'an eğitimine ihtiyaç duyulmaktadır. Kur'an dersinin niteliğini artırmak için öğretmenlerin meslekî yeterliklerinin yanı sıra, dersin öğretim programında yer alan kazanımlarının çok iyi bilinmesi ve dersin özel öğretim yöntem ve tekniklerinin uygulanması gerekmektedir. Yapılan araştırmada, İmam Hatip Okullarının 1924'ten itibaren Kur'an-1 Kerim dersi öğretim programlarında yer alan öğretim yöntemlerinin tespit edilmesi, var olan benzerliklerin ve farklılıkların ortaya çıkartılması, alan yazınında yer alan araştırmalardan yararlanılarak bu yöntemlerin ve uygulanma düzeyine dair verilerin değerlendirilmesi amaçlanmıştır. Araştırmada nitel araştırma deseninde doküman incelemesi yöntemi kullanılmıştır. Kronolojik sırayla geçmişten günümüze öğretim programlarında yer alan yöntem ve teknikler tespit edilerek analiz edilmiştir. Yapılan araştırmada MEB TTKB'nin ilgi sayı ve tarihli kararları ile Tebliğler Dergilerinde yayımlanan öğretim programlarındaki yöntem ve teknikler esas alınmıştır. 2016 yılından itibaren AİHL'lerde okutulan Kur'an-1 Kerim öğretim programı, öğretim yöntem ve teknikler önceki programlara nazaran geliştirilerek verildiği söylenebilir. Ancak, alan yazında yer alan araştırmalar incelendiğinde dersin öğretimine yönelik eleştirilerin devam ettiği ve öğretmenlerin mesleki yeterliliklerinin istenen düzeyde olmadığı sonucuna ulaşılmaktadır. Araştırma bulgularının, programda yer alan yöntem ve tekniklerin öğretmenlerce uygulama düzeyine ilişkin yapılacak çalışmalara katkı verici olması beklenmektedir.

Anahtar Kelimeler: İmam Hatip Liseleri, Kur'an-1 Kerim, Öğretim programları, Yöntemler.

\section{$\&$}

Abstract: Imam hatip high school graduates' professional competencies are supposed to be at adequate level of performing imamate, preaching and Quran course instruction. Also, a good instruction of Quran is required for students who prefer/will prefer Faculties of Theology/ Islamic Sciences. In order to increase the quality of the course of Quran - besides the required professional competencies of the teachers - the learning outcomes in the curricula of the course must be known by heart and the special teaching methods and techniques of the course must be applied. In the study, it was aimed to determine the teaching methods in the Quran curriculum of Imam Hatip Schools since 1924, to reveal the existing similarities and differences, to evaluate the data about these methods and their application level by 
using the existing researches in the literature. In this research, document analysis method was used as qualitative research design. The methods and techniques in the curriculum from the past to the present have been determined and analyzed in chronological order. The research was based on the decisions of the Board of Education of the Ministry of National Education with relevant numbers and dates, and the methods and techniques in the curriculum published in the Journal of Announcment. It can be said that the Quran curriculum, teaching methods and techniques, which have been taught at the Anatolian Imam Hatip High Schools since 2016, have been improved compared to previous programs. However, when the researches in the literature are examined, it is concluded that the criticism of the teaching of the course continues and the professional competence of the teachers is not at the desired level. It is expected that this research findings will contribute to future studies about the application level of the methods and techniques in teaching programs.

Keywords: Imam Hatip High Schools, The Noble Quran, Teaching programs, Methods.

(The Extended Abstract is at the end of the article)

\section{Giriş}

Osmanlı Devleti'nin son dönemlerinde medrese 1slah faaliyetlerine yönelik çalışmalar başlatılmıştır. 1909 yılında, öncelikli olarak Fatih Medreseleri'nde başlatılan bu 1slah hareketiyle uzun bir aradan sonra fen bilimlerine ve sosyal bilimlere ait dersler medreselerin müfredatında yer almıştır. Bu bağlamda, 1910 yılında çıkarılan Medâris-i İlmiyye Nizamnâmesi ile hesap, hendese, cebir, kimya, kozmoğrafya, hey’et gibi bazı fen bilimleri ile arih, coğrafya, felsefe gibi derslerin yeniden medrese programlarına eklenmesi için Şeyhülislam Mûsa Kazım Efendi'den fetva alınmıştır. Dönemin padişahı Sultan V. Mehmed (Reşad) zamanında başlatılan Tevcîh-i Cihat Nizamnâmeleri ile medreselerden din eğitimi ve din hizmetleri verecek vaiz, imam, hatip ve müezzin yetişmesi amacıyla İstanbul'da 1912 yılında Medresetü'l-Vâizîn, 1913'te de Medresetü'lEimme ve'l-Hutebâ açılmıştır.

1914 y1lında Islâh-1 Medâris Nizamnâmesi ile İstanbul'daki bütün medreseler Dârü'l-Hilâfeti'l-Âliye adı altında birleştirilmiştir (Öcal, 2017, s. 62-64) Evkâf-1 Hümâyûn Nezâretine bağlı olarak açılan bu iki medrese 1919 yılında 
Medresetü'l-İ́ş̧ad adıyla tek bir ad altında birleştirilmiş ve Vâizîn Şubesi ve Hutebâ ve Eimme Şûbesi adıyla iki şube olarak medreselerin kapanış tarihi olan 1924 yılına kadar devam etmiştir.

3 Mart 1924 yılında Türkiye Büyük Millet Meclisi'nde kabul edilen Tevhid-i Tedrisât Kanunu sonrasında 8 Mart 1924 tarihli Maarif Vekâleti'nin genelgesiyle kapatılan Dârü'l-Hilâfeti'l-Âliye Medreselerinin talebeleri, sınıf ve seviyelerine göre yeni açılan İmam ve Hatip Mektepleri'ne nakledilmiştir (Öcal, 2013, s. 12-32). Sonraki yıllarda açılanlar ile birlikte toplam sayıları 34 olan İmam ve Hatip Mektepleri bir süre eğitim ve öğretim faaliyetlerine devam etmiş, ancak bir takım gerekçelerle 1930 yılından itibaren kademeli olarak kapatılmıştır. En son, Kütahya ve İstanbul İmam ve Hatip Mektepleri 1933 yılında mezunlarını vermiş̧ir (Öcal, 2017, s. 136).

İmam Hatip Okulları, 1951-1952 öğretim yılında yeniden açılmış, okulların programları ve haftalık ders çizelgeleri yeniden hazırlanmıştır. Bu okullar ilk yıllarda, Millî Eğitim Bakanlığı Özel Okullar Müdürlüğü’ne bağlı olarak faaliyetlerini yürütmüştür. Daha sonra okulların iş ve işlemlerini yürütmek için müstakil bir birim olarak Din Eğitimi Müdürlüğü kurulmuştur (Öcal, 2019, s. 15-36). Genel Müdürlüğün adı 1983 yılında Din Öğretimi olarak değiştirilmiştir (Öcal, 2019, s.39-45). İmam Hatip Okullarının ve İmam Hatip Liselerinin Haftalık Ders Çizelgeleri ile Öğretim Programları, 1961 yılından bugüne kadar Din Öğretimi Genel Müdürlüğü tarafından hazırlanmakta ve Talim ve Terbiye Kurulu Başkanlığı'na sunulmaktadır. Talim ve Terbiye Kurulu Başkanlı̆̆ı'nda Kurul Üyeleri'nin müzakeresi sonucunda oylanan ve kabul edilen öğretim programları Bakan onayı sonrasında yürürlüğe girmektedir. Resmî veya özel yayınevleri tarafından hazırlanan ders kitapları da onaylanan öğretim programlarına göre hazırlanmakta ve Talim ve Terbiye Kurulu Başkanlığı'nın onayı sonrasinda okutulabilmektedir.

\section{İmam Hatip Okullarında Kur’an Öğretimi ve Yöntemleri}

İmam Hatip Liseleri, Kur'an öğretimi ve din eğitimi açısından merkezî bir konumda bulunmaktadır. Kur'an-1 Kerim dersi de bu okullardaki temel derslerin başında gelmektedir. Din eğitimi ve din hizmetleri alanındaki mesleklerin icrasında temel yeterlik Kur'an kıraatıdır. Millî Eğitim Bakanlığ "IHHL Meslek Dersleri Öğretmeni Özel Alan Yeterlilikleri”nde öğretmenlerin Kur'an-1 Kerim'i usulüne uygun olarak tilâvet etmesi, belirli sûreleri ezbere okuması ve öğrencilerin Kur'an-1 Kerim'i doğru ve güzel okuma, anlama ve yorumlama 
becerilerini geliştirebilmesine (MEB DÖGM İHL Meslek Dersleri Öğretmen Yeterlilikleri, 2015), “Anadolu İHL Öğrenci Meslekî Yeterlilikleri” nde öğrencilerin Kur'an-1 Kerim'i usûlüne göre okuma ve muhtevasını ana hatlarıyla tanıma becerilerini edinmelerine yer verilmiştir (MEB DÖGM İHL Öğrenci Yeterlilikleri, 2019).

İmam Hatip Liseleri ile İlahiyat/İslâmî İlimler Fakülteleri arasında sürekli öğrenci ve öğretmen akışı olmaktadır. İmam Hatip Liselerinden mezun olanların İlahiyat/İslâmî İlimler Fakültesini de tercih ettiği, bu fakültelerden mezun olanların bir kısmının ise İmam Hatip Okullarında öğretmen olarak görev aldığı görülmektedir. Her iki kurumdaki Kur'an eğitiminin niteliği birbirini olumlu veya olumsuz yönde etkilemektedir. İmam Hatip Liselerinde iyi bir Kur'an eğitimi alarak mezun olan öğrenciler İlahiyat/İslâmî İlimler fakültelerindeki lisans ve lisansüstü eğitimlerinde ve din hizmetlerinde daha başarılı olmaktadır. Fakültelerden Kur'an tilâvetinde meslekî yeterliliğe sahip olmadan mezun olanlar ise meslekî alanda başarılı olamamakta, öğrencilerin ve toplumun beklenti ve ihtiyaçlarına cevap verememektedir.

Kur'an-1 Kerim dersinin öğretiminde başarılı olunması için tilâvet becerisinden sonra dersin özel öğretim yöntem ve tekniklerinin bilinmesi ve uygulanmas1 gereklidir. Bu bağlamda öncelikle dersin öğretiminde öne çıkan geleneksel ve yaygın öğretim yöntemleri, öğrencinin hocasını dinleyerek öğrenmesi anlaminda kullanılan sema', hocasına okuması ve hocasının onu dikkatle dinlemesi anlamında arz (Pakdil, 2017, s. 30), sem'a ve arzın aynı anda uygulanmas1; Kur'an kelimelerinin hoca tarafından okunması ve ardından öğrencinin tekrar etmesiyle gerçekleşen ve yaygın olarak kıraat eğitiminde kullanılan edâ görülmektedir. (Yılmaz, 2016, s. 54; Tetik, 1990, s. 240). Tecvid öğretiminde nazariyyat ve tatbikat eğitiminin dengeli olarak birlikte verilmesi, belirli aralıklarla harf talimi yaptırılması ve koro uygulaması ile toplu okutmadan yararlanılması geleneksel ve yaygin yöntemlerin başında gelmektedir (Yılmaz, 2016, s. 5456). Kur'an öğretiminde genel öğretim metotları arasında yer alan öğrencilerin hazırbulunuşluklarının dikkate alınarak tedrice riayet edilmesi, egzersiz ve tekrarın da kullanılması ile grup çalışma yöntemi oldukça önem arz etmektedir (Biceğez, 2017, s. 91-92, 96). Belirtilen bu geleneksel ve yaygın yöntemler eğitim bilimlerindeki karşılıklarıyla değerlendirildiğinde sema'ın gösteri metodu ile örnek okuyuş yapılması ve okuyucunun modellenmesi; arz'ın geri dönüt alıp düzeltme; edâ'nın ise gösterip yaptırma ve geri dönüt alıp düzeltme; ders materyallerinden örnek okuyuş dinletilmesinin model gösterme; koro okuyuşu 
ve seviye gruplarının oluşturulmasının küme çalışması yöntemine tekabül ettiği veya benzer olduğu söylenebilir (Bkz.; Aydın, 2010, s. 288-290; Aş1koğlu, 2010, s. 553).

\section{Araştırmanın Amaci}

Yapılan araştırmada, 1924'ten günümüze kadar İmam Hatip Okullarında okutulan Kur'an-1 Kerim dersi müfredat/öğretim programlarında yer alan öğretim yöntem ve tekniklerinin tespit edilmesi, var olan benzerlikler ve farklılıklar ortaya çıkartılarak süreç içerisindeki gelişmelerin ve uygulamaya yansımasının değerlendirilmesi amaçlanmıştır.

\section{Yöntem}

İHL Kur'an-1 Kerim Dersi Öğretim Programlarında yer alan öğretim yöntem ve tekniklerine dair hususların geçmişten günümüze kadar kronolojik sıralamayla incelemeyi konu edinen bu araştırmada nitel araştırma desenlerinden doküman incelemesi yöntemi kullanılmıştır. 1924’ten bugüne kadar İmam ve Hatip Mekteplerinde, İmam Hatip Okullarında, İmam Hatip Liselerinde ve Anadolu İmam Hatip Liselerinde okutulan Kur'an-1 Kerim dersi öğretim programları, haftalık ders saati sayıları ve bu programlarda yer alan öğretim yöntem ve tekniklerine dair bilgiler incelenmiştir. Söz konusu programların listesi tabloda verilmiştir.

\begin{tabular}{ll}
\hline Tablo 1: Öğretim Programları Listesi \\
\hline S.N. & MEB Kararları, TTKB İlgi Sayı ve Tarihleri, Tebliğler Dergisi \\
\hline 1 & $\begin{array}{l}\text { Maarif Vekâleti Orta Tedrisat Müdür-i Umûmiliği, İmam ve Hatip Mektepleri Talimatnamesi, } \\
\text { 1924. }\end{array}$ \\
\hline 2 & $\begin{array}{l}\text { MEB Talim ve Terbiye Dairesi’ } 1952 \text { Tarih ve } 3 \text { Sayılı Kararı, İmam Hatip Okulları I. Devre } \\
\text { Müfredat Programları Hk. Kararı. }\end{array}$ \\
\hline 3 & $\begin{array}{l}\text { MEB Talim ve Terbiye Dairesi’ 1955 Tarih ve 213 Sayılı Kararı, İmam Hatip Okulları II. } \\
\text { Devre Müfredat Programları Hk. Kararı. }\end{array}$ \\
\hline 4 & $\begin{array}{l}\text { MEB Talim ve Terbiye Dairesi’ 1965 Tarih ve 181 Sayılı Kararı, İmam Hatip Okulları Müfre- } \\
\text { dat Programları. }\end{array}$ \\
\hline 5 & $\begin{array}{l}\text { MEB Talim ve Terbiye Dairesi’ 1972 Tarih ve 290 Sayılı Kararı, İmam Hatip Okulları Müfre- } \\
\text { dat Programı (MEB Tebliğler Dergisi, Cilt 35, sayı 1708). }\end{array}$ \\
\hline 6 & $\begin{array}{l}\text { MEB Talim ve Terbiye Dairesi’ 1973 Tarih ve 437 Sayılı Kararı, İmam Hatip Okulları Müfre- } \\
\text { dat Programı. (Bir önceki program aynen uygulanmıştır.) }\end{array}$ \\
\hline 7 & $\begin{array}{l}\text { MEB Talim ve Terbiye Dairesi’ 1978 Tarih ve 1 Sayılı Kararı, İmam Hatip Okulları Müfredat } \\
\text { Programı. (MEB Tebliğler Dergisi, Cilt 41, sayı 1973). }\end{array}$ \\
\hline 8 & $\begin{array}{l}\text { Eğitim ve Öğretim Yüksek Kurulu 1984 Tarih ve 9 Sayılı Kararı, İmam Hatip Liseleri Müfre- } \\
\text { dat Programı. (MEB Tebliğler Dergisi, Cilt 46, sayı 2151). }\end{array}$ \\
\hline
\end{tabular}




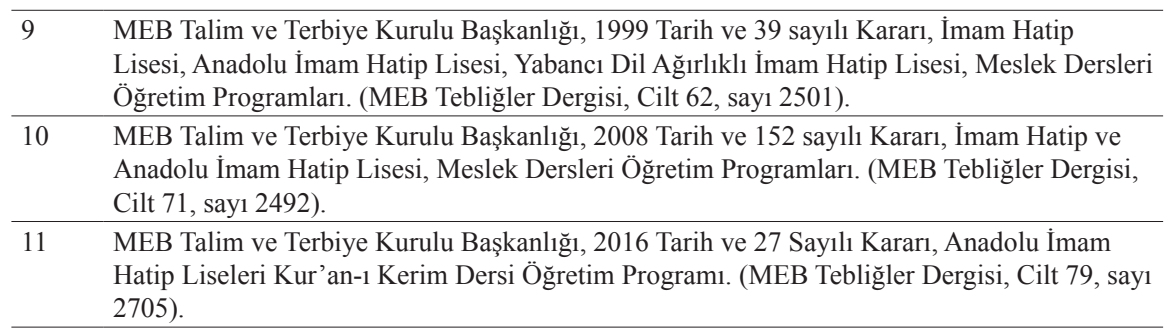

Millî Eğitim Bakanlığı Talim ve Terbiye Kurulu Başkanlığı ilgili sayı ve tarihli kararları, Tebliğler Dergilerinde yayımlanan öğretim programları, yöntem ve tekniklerin tespitine yönelik bilgilerin analiz edilme sürecinde kaynak oluşturmuştur. Yapılan araştırmada elde edilen bilgilerin uygulamaya yansıma durumu, alan yazınında yapılan bazı araştırmaların bulguları ile karşıllaştırılmıştır.

\section{Bulgular}

\section{İmam ve Hatip Mekteplerinde 1924-1933 Yıllarında Okutulan Kur'an-ı Kerim Müfredatında Öğretim Yöntem ve Teknikleri}

İmam ve Hatip Mektepleri 3 Mart 1924 yılında TBMM'de kabul edilen ve 6 Mart'ta da resmi ceride (gazete) de yayımlanarak yürürlüğe giren 430 Say111 Tevhid-i Tedrisat Kanunu'nun 4. Maddesi gereği açılmıştır (Öcal, 2013, s. 23). Açıldıkları yıl, İmam ve Hatip Mektepleri için "İmam ve Hatip Mektepleri Müfredat Programı” adıyla bir program hazırlanmış ve 1930 yılında kademeli olarak kapatılma sürecine girdikten sonra 1933 yılında öğrenciler mezun oluncaya kadar bu program uygulanmıştır.

29 Temmuz 1340 (29 Temmuz 1924) tarihli İmam ve Hatip Mektepleri Talimatnamesi'nde "Kur'an-1 Kerim Ma'a Tecvid" dersinin haftalık ders saati 1. ve 2. sınıflarda 3, 3. sınıfta 2, 4. sınıfta 1 saat olarak belirlenmiştir (Annadınç, 2019, s. 94-95). Osmanlı döneminde medreselerde ders vermiş, program geliştirme çalışmalarına öncülük eden Kamil Miras tarafından hazırlanan bu müfredat programında Kur'an dersi “Kur'an-1 Kerim Ma'a Tecvid" adıyla verilmiştir (Öcal, 2017, s. 136). İmam ve Hatip Mekteplerinde okutulan derslerin müfredat programları, Maarif Vekâleti tarafından bir kitapçık olarak neşredilmiştir (Döğen, 1992, s. 103).

Hazırlanan bu program, bir öğretim programından ziyade ders içeriklerinin yer aldığı bir müfredat mahiyetindedir. Bu yönüyle Erken Cumhuriyet Dönemi Türkiyesi'nde hazırlanan programlarla benzerlik arz etmektedir. İmam 
Hatip Mektepleri/Okulları/Liseleri’nin öğretim programları 1984 yılına kadar "Müfredat Programı" şeklinde tanımlanmıştır. Müfredat programları dersler ve konulardan müteşekkil olup bir programın temel unsuru olan amaç, kazanım ve değerlendirme bölümlerine yer verilmemiştir (Tunç, 2019, s. 60-61). Müfredat programında sadece okutulacak derslerden, bazı dersler için araç-gereç bilgisinden ve kısmen de olsa derslerde uygulanacak bazı uygulamalardan bahsedilmiştir.

"Birinci sinufta talebeden her birine sirayla Kur'an-ı Kerim okutturulup meharic-i hurûfa ehemmiyet verilecek. Tecvid'in en mühim kisımları uygulamalı olarak belletilecek, Kur'an-ı Kerim okutulurken ta'rifat ve tatbikat yapllacak, böylece talebenin tecvid hataları düzeltilecektir. İkinci sinufta ta'lim ve tecvide hasredilecek. Üçüncü ve dördüncü sinfflarda ta'lim ve tatbikata devam edilerek, edâ ve sadâya önem verilecektir. Küçük sûreler ile beraber Amme, Tebâreke, Fetih, Yasin ve bazı mühim sûre ve ayetler mutlaka ezber ettirilecektir (Döğen, 1992, s. 103)."

Müfredat programında tecvid kurallarının uygulamalı olarak verilmesi, Kur'an okutulurken uygulama becerisi de dikkate alınarak öğrencilerin hatalarının düzeltilmesi istenmiştir. Buradan hareketle müfredatta, sema' ve arz, harf talimi, takrir, tecvid öğretiminde nazariyat ve tatbikat dengesine riayet edilmesi ve tatbikata ağılık verilmesi (yaparak ve yaşayarak öğrenme) yöntem ve tekniklerinin öne çıktı̆̆ görülmüştür.

\section{İmam Hatip Okullarında 1951-1972 Yıllarında Okutulan Kur'an-1 Kerim Müfredat Programında Öğretim Yöntem ve Teknikleri}

Tevhid-i Tedrisat Kanunu ilka edilmediği halde kapatılan İmam ve Hatip Mektepleri, yirmi bir y1l aradan sonra 17.10.1951 tarihinde "İmam Hatip Okulu" adiyla Ankara, İstanbul, Adana, Kayseri, Konya, Maraş ve Konya illerinde yeniden açıldı (Öcal, 2013, s. 115). 4 yıllık olarak açılan bu yedi okulda Talim ve Terbiye Dairesi'nin 20 Kasım 1951 tarih ve 184 sayılı “İmam Hatip Okullarının ders dağıtım cetveli hakkında" kararına göre uygun görülen Haftalık Ders Çizelgesinde Kur'an-1 Kerim dersinin haftalık ders saatleri Kur'an-1 Kerim (Arap harfleriyle) ve Tecvit 1 . siniflarda haftada 2, 3. ve 4. siniflarda 1 saat, Kur'an-1 Kerim (Türk harfleriyle) ve Tecvit dersi ise her üç sınıf düzeyinde haftada 1 saat belirlenmiştir (MEB, 1951).

İmam Hatip Okulları için uygulamaya konulan bu çizelgeye göre 11 Ocak 1952 tarih ve 3 sayılı kararı ile "İmam Hatip Okulları birinci devre müfredat 
programlar hakkında" kararı ile Kur'an-1 Kerim dersi hariç Arapça, Tefsir, Akaid, Kelam, Din Dersleri, Siyer ve Ahlâk, Hadis Usûlü dersleriyle umumi kültür derslerinden Türkçe, Elyazısı, Tarih, Coğrafya, Yurttaşlık Bilgisi, Matematik, Fizik, Kimya, Tabiat Bilgisi, Sağlık Bilgisi, Müzik, Türk İslam Sanat, Yabancı Dil ve Resim-İş̧ derslerinin muhtevası kararlaştırılmıştır (MEB, 1951; MEB, 1952). Ancak, Kur'an-1 Kerim dersinin muhtevasına ait bilgilere yer verilmemiştir (Tunç, 2019 s. 70).

1951-1952 öğretim yılında açılan ilk yedi İmam Hatip Okulunun orta kısmı 1954-1955 yılında ilk mezunlarını vermiştir. Birinci devreleri 4, ikinci devreleri 3 sınıflı olmak üzere kurulan İmam Hatip Okullarından birinci devreden diploma alanlar "Orta Meslek Okulları"nı bitirenler gibi sayılmıştır (MEB, 1953). 1954-1955 öğretim yılında İmam Hatip Okulları ikinci devresine öğrenci almaya başlamış ve bu devreye ait yeni ders dağılım cetveli Talim ve Terbiye Dairesi'nin 1 Ekim 1954 tarih ve 190 sayılı kararıyla kabul edilmiştir. Buna göre Kur'an-1 Kerim dersinin haftalık ders saati, Kur'an-1 Kerim ve Tefsir adıyla 1., 2. ve 3. sinıflarda 3 saat olarak belirlenmiştir (MEB, 1954)

İmam Hatip Okullarının ikinci devresine öğrenci alınmaya başlandıktan tam bir yıl sonra da Millî Eğitim Bakanlığı’’nın tensibi ile Ankara İlahiyat Fakültesi öğretim üyelerinden Kemal Edip Kürkçüoğlu ve Rıfkı Melül Meriç’in ortak çalışmasıyla hazırlanan İmam Hatip Okulları ikinci devre taslak müfredat programının Talim ve Terbiye Dairesi'nin 1 Ekim 1955 tarih ve 213 sayılı kararı ile ileride İlahiyat Fakültesi Dekanlığı'ndan gelecek görüşler doğrultusunda gerekli tashihler yapılmak kaydıyla eğitim öğretimin aksamaması için o yıl uygulamaya konulması kararlaştırılmıştır. Uygulamaya konulan yeni programda Kur'an-1 Kerim dersinin adı “Kur'an-1 Kerim ve Tilâvet” olarak değiştirilmiştir. Kur'an-1 Kerim ve Tilâvet dersi haftalık ders saati 1. sınıflarda 2, 2. ve 3. sınıflarda 1 saat olarak belirlenmiştir (MEB, 1955).

"Kur'an-1 Kerim ve Tilâvet” dersi muhtevasıyla ilgili müfredat programında ayrıntılı olarak konulara yer vermemekle birlikte Kur'an-1 Kerim'in tecvit kaidelerine göre okunmasının kavratılması ve imkân nispetinde namazda okunmak üzere bir bütün olarak sûre ve geniş metinler ezberletilmesi istenmiştir (MEB, 1955). Yeni hazırlanan taslak Müfredat Programında Kur'an'1 Kerim derslerinin nasıl işleneceğine dair herhangi bir açıklama yer almamıştır.

İmam Hatip Okulları müfredat programlarında köklü değişiklik, okulların açılışından on dört yıl sonra yapılmıştır. Talim ve Terbiye Dairesi'nde incelenen İmam Hatip Okulları Müfredat Programları 8 Ekim 1965 tarih ve 181 sayı1ı 
kararla kabul edilmiştir. İmam Hatip Okullarının I. ve II. Devresini kapsayan müfredat programlarında ilk defa Türk Millî Eğitimi'nin amacına, İmam Hatip Okullarının tanımı, amaçları, bu okullardaki eğitim ve öğretim ilkelerine yer verilmiştir. Talim ve Terbiye Dairesi'nce alınan bu kararla okulların iki devreli yedi yıl $(3+4)$ süreli bir bütün olarak tasarlandığı, ortaokul kısmında temel dersler ile mesleğe hazırlık derslerinin okutulacağı, I. Devre mezunlarının ortaokul mezunu sayılacağı belirtilmiş, öğrencilerin imamlık ve hatiplik mesleğine yetiştirilmesinin esas olduğuna vurgu yapılmışıtır. Kur'an-1 Kerim dersinin haftalık ders saati sayısı da Kur'an-1 Kerim (Türk Harfleriyle) bütün sınıflar düzeyinde haftada 1 saat, Kur'an-1 Kerim (Arap Harfleriyle) 1. sinifta 1, 2. ve 3. sinifta 2 saat olarak belirlenmiştir (MEB, 1965). Bu müfredat programı 1971-1972 öğretim yılının sonuna kadar uygulanmıştır.

Müfredat programında dersin amacı "Kur'an-1 Kerim'in kurallarına göre doğru okunmasını sağlamak" olarak belirtilmiştir. Açıklamalar bölümünde ise belirtilen amaçların gerçekleştirilmesi için öğretim yöntemleri ve teknikleri açısından önceki programlara nazaran ilk defa aşağıdaki uygulamalara riayet edilmesi istenmiş ve başka bir ayrıntıya girilmemiştir.

"I. Devredeki haftallk ders saatlerinin 1 saati Türk harfleriyle yazll bulunan Kur'an-ı Kerim'den okutturulacaktır. Kulak terbiyesine önem verilmeli, ögrencilerin telaffuz yanlışları, bunların alışkanlık haline getirilmesine firsat vermeden düzeltilmelidir. Öğretmen, örnekleri önce kendisi okumal, sonra ögrencilerine tekrarlattırmalıdır. Bu konuda, tanınmış okuyucular tarafindan doldurulmuş plaklardan ve teyp bantlarından faydalanılmalıdır. Ezberlenecek metinlerde, kisalarından ve kolaylarından başlanılmak suretiyle uygun bir tedriç güdülmelidir (MEB, 1965).’”

Kur'an-1 Kerim dersi ile ilgili ilk defa konuların ayrıntılı olarak verildiği bu müfredat programında ilk sınıfta sadece kısa ibadet metinlerinin ezberletilip tecvid nazariyatına gidilmemesi, kulak terbiyesi için harflerin mahreçlerinden telaffuzunun ileriki sınıflarda ihtiyaç kalmayacak şekilde benimsetilmesine önem verilmesi istenmiştir. Dersin öğretim yöntemiyle ilgili olarak kulak terbiyesinin sağlanması ve telaffuz hatalarının tashihi için öğretmenin gösteri metoduyla önce kendisinin okuması, öğrencilerden aldığı geri bildirimlerle okuyuşları$\mathrm{n} 1$ kontrol etmesi istenerek geleneksel öğretim yöntemlerinden sem'a, arz ve edânın etkin bir şekilde uygulanması talep edilmiştir. O zamanki şartlara göre güncel ders materyalleri kullanılarak model gösterme yönteminden yararlanılması, ezber eğitiminde de kolaylaştırarak ve tedrice riayet ederek öğrencilerin seviyelerinin ve kabiliyetlerinin dikkate alınması istenmiştir. 
4 Ağustos 1971 tarih ve 225 sayılı Talim ve Terbiye Dairesi’ kararıyla İmam Hatip Okullarının orta kısmından meslek derslerinin çıkarılması öngörülmüş ve buna bağlı olarak da 20.04.1972 tarihli Talim ve Terbiye Dairesi'nin 248 sayılı kararıyla "İmam Hatip Okulları İdare Yönetmeliği” kabul edilmiş ve yürürlüğe girmiştir. Yeni öğretim yapısına göre yönetmelikte İmam Hatip Okulların tanımı yeniden yapılmış ve okulların 3+4=7 yıl şeklinde ortaokul üzerine dört yıllık öğrenim veren bir meslek okulu olduğuna, öğrencileri hem mesleğe ve hem de kendi alanında yükseköğrenime hazırladığına vurgu yapılmıştır (MEB, 1972a). Yeni duruma göre okulların haftalık ders çizelgesinde değişikliğe gidilmiş Kur'an-1 Kerim dersinin sadece ikinci devrede okutulması kararlaştırılmış ve yeni müfredat programı yürürlüğe girmiştir. Kabul edilen yeni çizelgede Kur'an-1 Kerim dersleri, lise 1. ve 2. sinfflarda haftada 5, 3. ve 4. siniflarda ise 4 saat olarak belirlenmiştir (MEB, 1972b). Ancak ders saatlerinde 28 Kasım 1972 yılında küçük bir değiş̧ikliğe gidilerek Lise 2. sınıflarda 4 saat, 4. sınıflarda ise 5 saat yapılmıştır (MEB, 1972c).

1972-1973 öğretim yllından itibaren okutulacak müfredat programında Kur'an-1 Kerim dersinin amac1, Kur'an-1 Kerim'in kendi kurallarına göre doğru okunmasını, imamlık ve hatiplik görevi için lüzumlu metinlerin ezberlenmesini sağlamak olarak belirlenmiştir. Dersin amacının gerçekleşmesi için 1965 y1lında kabul edilen programdaki uygulama esasları aynen alınmış, ilave olarak yüzünden okuma ve tecvid öğretimine dair yeni uygulama esasları verilmiştir.

"Yüzünden okuma ve ezber çalışmaları yapılırken bütün öğrencilerin önünde bir Kur'an-1 Kerim bulundurulmalı, bir öğrenci okurken diğerinin de göz ve kulakla metni takibi sağlanmalıdır. Ancak ezber metinlerde öğrenci öğretmenini önce yalnızca dinlemeli, sonra göz ve kulakla bu metinleri anında takip etmelidir. Tecvid konuları uygulamalı olarak işlenmeli; anlatılan bir konunun uygulaması seçme örneklerle anında yapılmalıdır (MEB, 1972b)."

Müfredat programında 9. sinıfta ibadet metinlerinin ezberletilmesi, nazari tecvid kurallarının öğretilmemesi, kulak terbiyesi vermek ve ileride düzeltilmesine ihtiyaç kalmayacak şekilde harflerin mahreçlerinin öğretilmesi istenmiş, başka bir ayrıntıya gidilmemiştir. Dersin öğretim yöntemiyle ilgili olarak bir önceki müfredat programında olduğu gibi sema', arz ve edâ yöntemine dikkat çekilmiş, sınıf yönetimi bağlamında öğrencilerin dinleyerek ve gözle takip ederek derse etkin katılımlarının sağlanması, tecvid öğretiminde tatbikata ağırlık verilerek konunun örneklerle iyice pekiştirilmesi istenmiştir. 


\section{İmam Hatip Liselerinde 1972-1984 Yıllarında Okutulan Kur'an-1 Kerim Müfredat Programında Öğretim Yöntem ve Teknikleri}

Bu döneme kadar "İmam Hatip Okulu" olarak bilinen ve son düzenlemeyle $3+4=7$ yıllık eğitim veren ve üniversiteye doğrudan öğrenci gönderemeyen, sadece kendi alanındaki yükseköğretim kurumlarına öğrenci gönderebilen okullar 1973 yılından sonra "Lise" statüsüne alınmıştır. (MEB, 1973a).

1739 Sayılı Millî Eğitim Temel Kanunu'nun kabulünden sonra İmam Hatip Okullarının müfredat programı yeniden değiştirilmiştir (MEB, 1973b). Yeni durumda okutulacak derslerle ilgili olarak Talim ve Terbiye Dairesi'nin 28 Kasım 1972 tarih ve 354 sayılı kararı ile kabul edilen Haftalık Ders Çizelgesine devam edilmesi ve derslerin dağılımında herhangi bir değişikliğe gidilmemesi de kabul edilmiştir. Orta kısma ise meslek dersleri yeniden konulmuştur. Kur'an-1 Kerim dersi saatleri Orta 1, 2 ve 3'te haftada 3 saat olarak belirlenmiştir. Yapılan müfredat değişikliğinde Kur'an-1 Kerim dersine ilave konular eklenmemiş, sadece yüzünden okunacak bazı bölümlerin bir önceki veya sonraki sınıfa aktarılması yetinilmiştir. Dolayısıyla dersin öğretim yöntem ve tekniklerine dair bir önceki program olan ve 1 Temmuz 1972'de kabul edilen İmam Hatip Okulları Müfredat Programındaki bölümler aynen devam etmiştir (MEB, 1973b)

1977 yılında İHL Müfredat Programları ile Ders Dağılım Çizelgelerinde tekrar değişikliğe gidilmiş ve bu bağlamda Kur'an-1 Kerim dersi müfredat programında da değişiklikler yapılmış, dersin haftalık ders saati sayısı bütün sınıflar düzeyinde haftada 3 saat olarak belirlenmiştir (MEB, 1978). Yeni müfredat programında dersin amacı Kur'an-1 Kerim'in kendi kurallarına göre doğru okunmasını, imamlık, hatiplik ve Kur'an kursu öğreticiliği görevleri için gerekli bilgi ve metinlerin bellenmesini ve uygulamasının yapılmasını sağlamak olarak belirtilmiştir. Dersin konularında değişiklik yapılmış fakat öğretim yöntem ve tekniklerine dair 1972 tarihli öğretim programında yer alan uygulama esasları aynen alınmıştır (MEB, 1978).

Okullara lise statüsü verilmesiyle başlayan yeni dönemde müfredat programlarında Kur'an-1 Kerim dersinin öğretim yöntemlerine dair yenilikler olmamış, önceki programda dikkat çekilen geleneksel metotlarla kulak terbiyesinin sağlanması, telaffuz hatalarının düzeltilmesi, ezberde tedrice riayet edilmesi, tecvid öğretiminde ise tatbikata ağırlık verilmesi ile yetinilmiştir. 


\section{İmam Hatip Liselerinde 1984-1999 Ylllarında Okutulan Kur'an-1 Kerim Öğretim Programlarında Öğretim Yöntem ve Teknikleri}

1984 yılında İHL orta ve lise kısmı öğretim programı yeniden hazırlanmıştır (MEB, 1984). Din Öğretimi Genel Müdürlüğ̈̈’nün teklifi ile Talim ve Terbiye Kurulu Başkanlığınca incelenen ve Bakan Onayı ile uygun görülen programın 1984-1985 öğretim y1lında uygulamaya konulması için Eğitim ve Öğretim Yüksek Kurulu'na sunulması kararlaştırılmıştır (MEB, 1985). Eğitim ve Öğretim Yüksek Kurulu'nun 11.12.1984 tarih ve 9 sayılı kararlarıyla da yürürlüğe girmiştir. Aynı kararla kabul edilen yeni öğretim programlarının Talim ve Terbiye Kurulunca 11.10.1983 tarih ve 177 sayılı kararlarla kabul edilen İHL orta ve lise kısmı Haftalık Ders Çizelgelerine göre uygulanması kararlaştırılmıştır (MEB, 1983). Buna göre yeni programın uygulanacağı Kur'an-1 Kerim dersinin haftalık ders saatleri İmam Hatip Ortaokullarında Orta 1, 2 ve 3 'te haftada 5 saat, Lise-1 ve 2'de 4, Lise-3 ve 4'te ise 3 saat olarak belirlenmiștir (MEB, 1984).

1984 yılında yayımlanan Kur'an-1 Kerim dersi öğretim programının geneline bakıldığında haftalık ders saatlerinin yeterli olduğu görülmektedir. Öğretim programında Kur'an-1 Kerim dersinin genel amaçlarına ayrıntılı olarak yer verilmiştir:

"Kur'an-ı Kerim'i kurallarına göre okuyabilme, bazı dua, ayet ve sûreleri ezberleyebilme, tecvid bilgisi ve kurallarını uygulayabilme, Kur'an-ı Kerim'i okumaya ve ezberlemeye ilgi duyabilme, Kur'an'a sayg duyabilme, Kur'an okumayı ögretmenin ve öğrenmenin faziletini anlayabilme, kurallarına uygun olarak Kur'an okumayı başarmanın gururunu ve sevincini duyabilme, İmam Hatiplik ve Kur'an kursu ögreticiliği gibi mesleki görevler için olan bilgi ve beceri kazanabilme, yedi yıllık süre içerisinde Kur'an-ı Kerim 'in tamamını kurallarına göre yüzünden okuyabilmedir (MEB, 1984)."

Program ayrıntılı olarak incelendiğinde yüzünden okumada Kur'an'ın tamamının okunması ve yeterince sûre ezberlenmesi planlanmıştır. Programda anlam ünitelerine yer verilmemiş, tecvit bilgileri ise yeterli düzeyde alınmıştır. Kısmen Kur'an bilgisi ve o günkü program tasarımına göre yeterince Kur'an öğretim yöntemleri ve teknikleri bilgisine yer verilmiştir. 1984-1985 öğretim y1lında uygulamaya konulan öğretim programında 'Kur'an Öğretimi İle İlgili Açıklamalar" başlığı altında dersin öğretim yöntem ve tekniklerine dair temel esaslara ilk defa genişçe yer verilmiştir.

Kur'an-1 Kerim dersi işlenirken öncelikle her öğrencinin kulak ve ses eğitimi ile ezberleme kabiliyetinin bir olmadığının göz önünde bulundurularak ferdi 
farklılıkların esas alınması, başlangıçta Kur'an harflerinin kalınlık ve incelik özelliklerinin uygulamalı öğretiminin yapılması, yüzünden ve ezber okumalarda Kur'an alfabesi ve Kur'an-1 Kerim bulundurulmas1, sıra takip edilmemesi ve diğer öğrencilerin dinlemelerinin sağlanması istenmiştir. Ses ve kulak terbiyesine önem verilerek telaffuz hatalarının alışkanlık olmadan ve öğrenciler mahcup edilmeden düzeltilmesi, doğru sesi vermekte zorlanan öğrencilere kolaylık gösterilip zamana bırakılması talep edilmiştir. Öğretmenlerin ağır ağır örnek okuyuş yapması belirtilmiş, plak ve teyp bantlarından yararlanılması önerilmiştir. Tecvid konularının uygulamalı öğretilmesi ve ezber veya yüzünden iyi olan yerlerle bu uygulamaların pekiştirilmesi, ezberlerde kısa ve kolay yerlerden başlanarak tedriciliğe riayet edilmesi, ezberlerin önceden hatasız okunmasının sağlanmasi, Kur'an alfabesi, ezberlenecek dua, sûre ve ayetlerin ev ödevi olarak yazdırılması istenmiştir. (MEB, 1985, s. 30-31).

Öğretim programı "Konu, Amaç, Davranışlar, İşleniş ve Değerlendirme" başlıkları altında tasarlanmıştır. Buna göre uygulamayla ilgili açıklamaların verilmesiyle yetinilmeyerek yüzünden, ezber ve tecvid konularının örnek işlenişlerine de yer verilmiştir. Öğretim yöntemleri açısından değerlendirildiğinde, yüzünden okuma bölümlerinde dersin işlenişinde öncelikle öğretmenin gösteri yöntemi ile iki sayfa örnek okuyuş model okuma yapması ve bu esnada öğrencinin dikkatlice dinleyerek takip etmesi sema', sıra takip etmeksizin bu iki sayfanın öğrencilere okutulması arz ve diğerlerinin takip etmesinin sağlanması, sayfalar bitince de başa dönülmesi ve diğer yüzünden okuma derslerinin de aynı metotla işlenmesi istenmiştir.

Ezber bölümleriyle ilgili ders işlenişinde öğretmenin birkaç defa ağır ağır örnek okuyuş yapması ve öğrencilerin dikkatle dinlemelerinin sağlanması, sonra sıra takip etmeksizin yüzünden öğrencilere okutulması ve diğer öğrencilerin arkadaşlarını dinlemesi, hataların mahcup edilmeden geri dönüt alınıp düzeltilmesi, bazen de öğrencilerin hatalarının tespit edilip sonunda hatırlatılması, ezberlenecek dua ve sûrelerin koro okuyuşuyla tekrar edilmesi, ezberi zayıf öğrencilere birkaç defa yüzünden okutulması, tecvid kurallarının açılanması ve bu kurallara riayet edilerek okunması, kulak eğitiminin geliştirilmesi için varsa teyp kasetinden dinletilmesi istenmiştir.

Tecvit öğretiminde dersin işleniş̧inde öğrencilerin önünde Kur'an-1 Kerim veya cüzü, defter ya da tecvid kitabının bulundurulmasının sağlanması, tecvid kuralı örneklerinin tahtaya yazılması ve model okuma yapılmas1, ayetler üzerinde örneklerin bulunması buldurma, pekiştirinceye kadar ayetler üzerinde 
uygulamaya çalışmalarının sürdürülmesi, yüzünden veya ezber okunan bölümlerde geçen tecvid kurallarının usulüne uygun olarak okunması ve yer yer açılamalar yapılarak iyice kavranıncaya kadar yürütülmesi, öğrencilerin tilâveti sırasında geri dönüt alıp tecvid hatalarının düzeltilmesi, öğrencilerin okunan ayetlerdeki tecvid kurallarını söylemesi talep edilmiştir. Ayrıca tecvid öğretimine yönelik 9. sınıfta "Tecvid" bölümünde "Tecvid İlmini Öğrenmede Fem-i Muhsin'e duyulan İhtiyaç" başlığına da yer verilmiştir.

Bu dönem uygulanan Kur'an-1 Kerim Dersi Öğretim Programının en önemli özelliği Kur'an-1 Kerim öğretim yöntem ve teknikleri ile ilgili müstakil bir bölüme yer verilmesidir. 12. sınıfta “Kur'an Öğretimi Bilgisi ve Kur'an Öğretimi Metodlarını Uygulayabilme" amaçları belirlenmiş ve bu bağlamda "Kur'an öğretimi bilgisi, Kur'an öğretiminin fazileti, Kur'an öğretiminde kolaydan-zora, kısadan-uzuna gitme, Kur'an öğretiminde belli aralıklarla tekrarın önemi, ses ve kulak terbiyesi, tecvid kurallarını tedrici olarak öğretme, öğretimde öğrencilerin kapasite ve kabiliyetlerini göz önünde bulundurma" konularına yer verilmiştir (MEB, 1985, s. 30-31).

Programın genel bir değerlendirmesi yapıldığında "Dersin/Programın Uygulanmasıyla İlgili Açıklamalar” bölümünün öğretim programında ünite olarak yer aldığı, 12. sınıfta bulunması itibariyle de programın tamamına yansımasının mümkün olmadığı ve sadece o sınıfın dersine giren öğretmenle sınırlı olduğu görülmektedir.

\section{İmam Hatip Liselerinde 1999-2008 Yıllarında Okutulan Kur'an-1 Kerim Öğretim Programlarında Öğretim Yöntem ve Teknikleri}

1997 Şubat ayında başlayan ve kamuoyunda 28 Şubat süreci olarak bilinen dönemin en önemli uygulamalarından birisi olarak 16 Ağustos 1997'de TBMM'de kabul edilen "8 y1llık kesintisiz eğitim yasası ile İmam Hatip Liselerinin orta kısmının kapatılmış olmasıydı. Bu yasanın gereği olarak İHL'lerin orta kısmına o yıldan sonra öğrenci alınmamış ve 1999 yılından itibaren de İmam Hatip Liseleri hazırlık $+3=4$ yıl olarak tasarlanmıştır.

Bu bağlamda Din Öğretimi Genel Müdürlüğü'nce 09.04.1999 tarih ve 1341 sayılı yazı ile teklif edilen yeni program Talim ve Terbiye Kurulu Başkanlığınca 10.05.1999 tarih ve 39 sayılı karar ile kabul edilmiştir (MEB, 1999a). Aynı karar ile Eğitim ve Öğretim Yüksek Kurulunun 11.12.1984 tarih ve 9 sayılı kararlarıyla kabul edilen öğretim programının lise kısmı İHL meslek dersleri öğretim programları yürürlükten kaldırılmıştır. 
Kurul tarafından kabul edilen yeni meslek dersleri öğretim programı 19992000 öğretim y1lından itibaren uygulamaya konulmuştur (MEB, 1999b). Öğretim programı 1998 yılında Talim ve Terbiye Kurulu Başkanlığınca kabul edilen ve Kur'an-1 Kerim dersi için belirlenen haftalık ders saatlerine (MEB, 1998) göre uygulanmıştır. Buna göre Kur'an-1 Kerim dersi Hazırlık sınıflarında haftada 8 saat, Lise-1, 2, 3 ve 4. sinıflarda ise 4 saat olarak belirlenmiştir.

Yeni sistemde İmam Hatip Liselerine 1 yıl hazırlık sınıfı getirilmişti ve haftada 8 saat Kur'an dersi konulmuştu. Hazırlık sınıfını da içerecek şekilde hazırlanan program öncekilerden farklı olarak lafız-mânâ bütünlüğünü dikkate alarak, anlam ünitelerine de ağıllık vermiş̧tir. Öğretim Programında dersin genel amaçları:

“Kur'an-ı Kerim tarihini ve Mushafin oluşum sürecini ana hatlartyla bilme; Kur'an-ı Kerim 'in indirildiği dönemdeki işlevini ve niteliklerini kavrama; doğru ve güzel bir biçimde yüzünden okuma; Kur'an-ı Kerim'de belirlenen bölümleri ezberden okuma; Kur'an-ı Kerim'in verilen bölümlerinin meallerini okuyup onlardan güncel değerler çıkarma; meslekî ve kişisel yaşantıda etkin bir biçimde kullanabileceği ve insanın ahlâkî yönünü doğrudan olumlu etkileme niteliğine sahip klsa ayet metinlerini ezberleme; içinde bulunduğu psikolojik, toplumsal ve tarihî koşulları Kur'an-ı Kerim'e ait değerlerle ilişkilendirmedir (MEB, 1999b).",

$\mathrm{Bu}$ genel amaçlar çerçevesinde işlenecek Kur'an dersi için dersin öğretim yöntem ve tekniklerine dair Programın "Uygulamayla İlgili Genel Açılamalar" bölümünde daha önceki programlardan farklı olarak öğretmenlere temel yöntem bilgileri verilmektedir. Bu bağlamda öne çıkan uygulamalar, yöntem ve teknikler zikredilecektir.

Öğretmenler tarafından ezberlenecek sûre ve ayetlerin sınıfta birkaç kez okuyarak sema' metodunun uygulanması ve model gösterme ile ilgili ders materyallerinden yararlanılması, ezberlenecek bölümlerin parçalar halinde koro okuyuşu ile iyice kavratılması talep edilmiştir. Anlam öğretiminde meali okunacak bölümlerden değerler çıkarılması için beyin firtınası tekniği vb. etkinliklerin gerçekleştirilmesi, ayet mealleri ile ilgili soru-cevap metodu başta olmak üzere öğrencileri güdüleyecek yöntemlere başvurulması belirtilmştir. Kur'an öğretiminde tekrarın önemine vurgu yapılarak, önceki ezberlerin tekrar edilmesine ve yeri geldikçe tecvid kurallarının hatırlatılmasına vurgu yapılmıştır. Yüzünden okumada sıra takip edilmeksizin öğrencilerin sürekli ilgisinin canlı tutulması, ölçme ve değerlendirmede bireysel farklılıkların göz önünde bulundurulması ve ezber bölümlerin anlamlarının kısaca açıklanması belirtilmiştir. (MEB, 1999b) 
Öğretim programında "Kur'an Öğretiminde Temel İlkeler” adı ile müstakil bir konu başlığı verilmiştir. Ancak burada kazanımlar ve ayrıntılı muhteva bulunmamaktadır. Öğretim programına göre sadece hazırlık sınıfı için ders kitabı hazırlanmış ve belirtilen konuya yer verilmiştir. Hazırlık sınıfı düzeyinde işlenen konu başlığı altında ders kitabında "Bireysellik, Görsellik, İşitsellik, Tekrarlama, Ezberlemeden Önce Doğru Okuma, Türkçe'deki Seslerden Yararlanma, Kur'an'dan Değer Üretmeye Özendirme ve Öğrencinin Ahlâkî Olanı Özümsemesine Katkı Sağlama” ilkeleri ve bu ilkelerin çok kısa açıklaması yer almaktadır (Albayrak ve Serinsu, 2004, s. 25-27).

1999-2008 yılları arasında okutulan Kur'an-1 Kerim dersi öğretim programının uygulandığı dönemde dersin uygulama esaslarına yönelik değerlendirmeler Ensar Vakfı Değerler Eğitimi Merkezinde 6-7 Aralık 2003 tarihinde gerçekleştirilen "İmam Hatip Liselerinde Eğitim ve Öğretim Sempozyumu”nda yapılmıştır. Bu sempozyumda, Kur'an-1 Kerim dersi öğretim programıyla ilgili değerlendirmeler yapan bildiriler olmuş ancak dersin öğretim yöntem ve teknikleri sadece bir bildiride konu edilmiştir. Burada da Kur'an-1 Kerim dersi öğretim programındaki yöntem ve tekniklerin ayrıntılı olarak tahlil edilmediği ancak “Öğretim Teknikleri” başlı̆̆ında Kur'an öğretimi ile ilgili genel ilke ve yöntemler üzerinde durulduğu görülmüştür (Çollak, 2005, s. 134). Değerler Eğitimi Merkezi tarafindan İmam Hatip Liseleri Meslek Derslerinin öğretim programlarıyla ilgili bahsi geçen sempozyumdaki akademisyenlerin ve öğretmenlerin görüş ve önerilerinden yararlanarak çalışmalar yürütecek müstakil komisyonlar kurulmuştur. Komisyonun hazırladığı ve Değerler Eğitimi Merkezi tarafindan Din Öğretimi Genel Müdürlüğüne 16.04.2004 tarihinde sunulan raporda Kur'an-1 Kerim dersinde uygulanması gereken öğretim yöntem ve tekniklerine dair bazı öneriler getirilmiştir. Buna göre; ilk okuma düzeyinde harf ta'limi yaptırılması, öğrencilerin seviyelerinin dikkate alınması, akran desteğinden yararlanılması, cami uygulamaları ile öğrencilerin okuma becerilerinin pekiştirilmesi, tecvid bilgilerinin ayrıntıya gidilmeden sade anlatılması, hafız öğrencilerin hafızlıklarının korunmasına yönelik çaba sarfedilmesi, yüzünden okunacak bölümlerin ders kitabında verilirken Mushaf'taki sıralamaya göre verilmesi, kitabın birinci ünitesinin müstakil elif-bâ olarak hazırlanması teklif edilmiştir (Salman, Y1lmaz ve Morgül, 2004).

1999-2008 yılları arasında uygulanan bu programda yüzüne okunan bölümler ve ezber bölümler önceki programa göre azaltılmıştır. Bunun sebebi de sekiz yıllık kesintisiz eğitim sebebiyle İmam Hatip Liselerinin orta kısımlarının 
kapatılmasıdır. Hazırlık sınıfı ile birlikte dört yıllık bir eğitimden mezun olan öğrenci toplamda 720 ders saati Kur'an eğitimi almıştır.

1999 yılında hazırlanan programın önemli bir özelliği Kur'an-1 Kerim'in muhtevasının öğretimini de öncelemesi ve anlam ünitelerinin olmasıdır. "Kur'an'a Ait Değerler ve Dayanakları" ve "Ezberlenecek ve Yorumlanacak Ayetler" bölümü lafız öğretiminin yanında anlam öğretimine de önem verildiğinin göstergesidir. Bu dönemde okutulan tecvid konuları lise seviyesi için yeterli düzeydedir. Öte yandan programda “Örnek İşleniş” başlığı altında Kur’an’a Ait Değerler ve Dayanakları ile ilgili 40 dakika üzerinden örnek bir ders anlatımına da yer verilmiştir. "Örnek İşleniş" başlığı altında verilen ders işleme metodu ise tamamen anlam merkezli olup "Kur'an'a Ait Değerler ve Dayanakları" ünitelerinde konu merkezli tasnif edilen ayetlerin açıklamasına dair soru-cevap ve anlatım metodu bağlamında bazı teknikler ele alınmıştır.

1999-2008 yılları arasında 9 yıl okutulan öğretim programda lafız öğretimi, anlam öğretimi ve tecvid öğretiminde teori ve uygulama becersinin verilmesine dair temel uygulama esasları ve öğretim yöntemleri ayrınıtılara girilmeden bir önceki programa nazaran biraz daha geliştirilerek verilmiştir.

2005 yılında Talim ve Terbiye Kurulu Başkanlı̆̆ı'nın 24.11.2005 tarih ve 353 sayılı kararı ile İmam Hatip Liseleri Haftalık Ders Çizelgeleri 9. Sınıftan itibaren yeniden düzenlenmiş ve 1998 yılında hazırlanan öğretim programının uygulamasına devam edilmiştir (MEB, 2005). Yeni düzenlemeyle Kur'an-1 Kerim dersi Lise-1'de 4, Lise-2'de 7, Lise-3'te 6, Lise-4'te 5 saat olarak belirlenmiştir. Anadolu İmam Hatip Liselerinde ise Lise-1'de 3, Lise-2'de 7, Lise-3 ve Lise-4'te 4 saat olarak belirlenmiştir.

\section{İmam Hatip Liselerinde 2008-2016 Yillarında Okutulan Kur'an-ı Kerim Öğretim Programlarında Öğretim Yöntem ve Teknikleri}

Din Öğretimi Genel Müdürlüğü’nün 19.06.2008 tarih ve 1375 sayılı yazısıyla teklifi üzerine yeni hazırlanan İmam Hatip Lisesi ve Anadolu İmam Hatip Lisesi Meslek Dersleri öğretim programı Talim ve Terbiye Kurulu Başkanlığı'nın 22.07.2008 tarih ve 152 sayılı Kararı ile kabul edilmiştir (MEB, 2008a). Aynı karar ile 10.05.1999 tarih ve 39 sayılı karar ile önceki program uygulamadan kaldırılmıştır (MEB, 2008b, s. 458). Bir süre (2 öğretim yıl1) önceki Haftalık Ders Çizelgesine göre okutulan program, 2010 yılında değişikliğe gidilerek yeni çizelgeye göre okutulmuştur. Buna göre, Kur'an-1 Kerim dersinin yıllara 
göre haftalık ders saatleri Lise-1'de 6 (Anadolu İHL-4), Lise-2'de 7, Lise 3 'te 6 ve Lise-4'te 4 saat olarak belirlenmiştir (MEB, 2010).

Anadolu İmam Hatip Liseleri ve İmam Hatip Liseleri Kur'an-1 Kerim Dersi öğretim programının giriş kısmında dersin öğretim yöntem ve tekniklerine vurgu yapılmıştır (MEB, 2008a, s. 26). Dersin genel amaçları ve programın temel çatısı ile ilgili de aşağıdaki ifadelere yer verilmiştir:

“Kur'an-1 Kerim dersini alan öğrenciler; Kur'an-1 Kerim’i doğru ve güzel okumanın İslam dinindeki ve kültürümüzdeki yerini fark eder. Kur'an-1 Kerim harflerini mahrecine ve tecvit kurallarına uygun olarak doğru ve güzel bir biçimde okur. Bazı sûre ve ayetleri kurallarına uygun olarak ezberler ve gerektiğinde okur. Programda yer verilen ayet ve surelerin anlamlarını yorumlar ve ilkeler çıkartma becerisi kazanır (MEB, 2008a, s. 26).”

Programda anlam üniteleri olarak sadece ezberlenen ayet ve surelerin anlamı istenmiştir. Tecvid konuları lise seviyesi bir eğitim için yeterli olarak verilmiştir. Programın en önemli özelliği ve bir önceki programlardan ayıran tarafı her bir öğrenme alanıyla ilgili üniteler ve kazanımlar verildikten sonra "Etkinlik Örnekleri” ve "Açıklamalar" kısmıyla bir bakıma daha önceki programlarda "Uygulamayla İlgili Genel Açıklamalar" başlığı altında verilen dersin işlenişine dair yöntem, teknik ve materyal kullanımına dair önerilerin ayrıntılı olarak her bir öğrenme alanı, üniteler ve kazanımlarla ilişkilendirilerek verilmiş olmasıdır. Önceki programlarla mukayese edildiğinde dersin daha etkin ve verimli olmasının temini için geliştirilen ve programda yer alan yöntemler ve etkinlik örnekleri olumlu bir gelişme olmuştur.

Programın “Açıklamalar” bölümünde ise öğretim yöntemleriyle ilişkili olarak uygulamaya yönelik ünite işlenirken öğrencilerin okuma, dinleme ve uygulama etkinliklerine öne verilmesi, öğrencilere verilecek beceriler arsasında Kur'an-1 Kerim'i doğru ve güzel okuma, anlama ve yorumlama, bilgi teknolojilerini kullanma, harfleri tanıma ve mahreçleri doğru telaffuz etme öncelenmiştir. Sûre ve duaların ezberiyle ilgili kazanım işlenirken de öğretmenin önce kendisinin okuması veya meşhur bir okuyucudan örnekler dinletmesi, yüzünden okumalarda öncelikle öğretmenin okuması istenmektedir (MEB, 2008a, s. 31-46).

Öğretim programının “Etkinlik Örnekleri” ve “Açıklamalar” bölümünde dersin işlenişinde öğretim yöntem ve teknikleri olarak; sema', arz, edâ, buldurma, soru-cevap, küme çalışması, toplu okuma ve okutma, takrir, taklit etme, problem çözme, model gösterme, gözlem, bireysel çalışma, beyin firtınası, eğitsel 
oyun, işbirliğine dayalı öğrenme, örnek olay incelemesi, rol yapma, panel ve küçük grup tartışma tekniği öne çıkmaktadır (MEB, 2008a, 31-46; Aydın 2011a, s. 281-294)

Kur'an-1 Kerim dersi öğretim programının son bölümünde 'Kur'an-1 Kerim Dersi $(9,10,11$ ve 12. Sinıflar) Öğretim Programı Örnek Etkinlik Uygulamaları" adıyla müstakil bir başlık açılmış ve etkinliklerin nasıl uygulanacağına dair örnek etkinlik çalışması da yapılmıştır. Örnek uygulaması verilen etkinlikler "Harflerin Yeri, Hep Beraber, Bul ve Söyle, Anlaşılmak İçin İnmiştir, Öğrenelim Uygulayalım, Birbirimizi Dinliyoruz, İlkeler Tespit Ediyoruz, İlkeler Çıkarıyoruz, Her Şey Güzel Okumak İçin, Bizim İçin Ne Anlam İfade Ediyor, Seri Ama Hatasız" başlıklar altında yer almaktadır (MEB, 2008a, s. 51-62).

Program geliştirme açısından bakıldığında Kur'an-1 Kerim dersi öğretim yöntem ve tekniklerinde yeni uygulamaların müfredata yansıması açısından gelinen bu noktanın oldukça iyi bir durum olduğu söylenebilir.

\section{Anadolu İmam Hatip Liselerinde 2016 Yılından İtibaren Okutulan Kur'an-1 Kerim Öğretim Programlarında Öğretim Yöntem ve Teknikleri}

2014-2015 Öğretim yılında bütün İmam Hatip Liselerinde “Anadolu İmam Hatip Lisesi Programı" uygulanmaya başlanılması ve öğretim programlarının da sadeleştirilmesi saikıyla öğretim programlarında değişikliğe gidilmiştir. Bu bağlamda 2016-2017 öğretim yılından itibaren Anadolu İHL Kur'an-1 Kerim Dersi Öğretim Program1 9. Sınıftan başlayarak kademeli olarak uygulanmaya başlamıştır (MEB, 2016, s. 345). Kur'an-1 Kerim derslerin saatleri 9. sınıfta 5, 10. ve 11. sinifta 4, 12. sinifta ise 3 saat okutulmaktadir (MEB, 2017, s. 156). 2016 y1lından itibaren okutulan Anadolu İmam Hatip Liseleri Kur'an-1 Kerim Dersi Öğretim Programında dersin genel amaçları şöyle belirtilmiştir:

Kur'an-1 Kerim'i doğru ve güzel okumanın İslam dinindeki ve kültürümüzdeki yerini fark eder. Kur'an-1 Kerim'i doğru ve güzel okuma kurallarını açıklar. Kur'an-1 Kerim'i harflerin mahreçlerine ve tecvid kurallarına uygun olarak doğru ve güzel bir biçimde okur. Gerek meslekî hayatında gerekse kişisel hayatında etkin bir biçimde kullanabileceği bazı sure ve ayetleri kurallarına uygun olarak ezberler ve okur.Programda yer verilen ayet ve surelerin anlamlarından temel ilkeler çıkarma becerisi kazanır (MEB, 2016, s. 345). 
Dersin öğretim programının "Uygulanmasına İlişkin İlke ve Açıklamalar” ile ünite kazanımlarıyla ilgili “Açıklamalar” bölümleri göz önünde bulundurularak Kur'an-1 Kerim öğretim yöntem ve teknikleri açısından değerlendirildiğinde öne çıkan hususları şu şekilde sıralanmaktadır:

Kur'an öğretiminde temel bir ilke olan harf talimine, edâ yöntemi ile öğretmen-öğrenci karşılıklı okumaya ağırlık verilmiş ve belirli aralıklarla gerçekleştirilmesi istenmiştir. Tecvid öğretiminde takrir yöntemiyle sade bir anlatım ve uygulama ağırlıklı bir öğretim vurgulanmıştır. Anlam öğretimi açısından lafız-mânâ bütünlüğüne katkı verecek şekilde yüzünden veya ezberden okunan bölümlerde yeri geldikçe nüzul sebepleri zikredilerek farklı anekdotlarla güncel mesajlar çıkarılması için buldurma, soru-cevap yöntemi ve beyin firtınası, küçük grup tartışma tekniğine başvurulması talep edilmiştir.

Kur'an-1 Kerim'in okunmasını ve öğrenilmesini teşvik eden ayet ve hadislerden yararlanılması istenmiştir. Öğrencilerin ayetleri yorumlama becerilerini geliştirmeye yönelik bireysel çalı̧̧ma, problem çözme, buldurma ve küme çalışması yöntem ve teknikleriyle mealler üzerinden okuma-anlama-yorumlama etkinliği yapılmasına dikkat çekilmiştir.

Kur'an öğretiminde temel bir metot olan sema' ile bir okuma tavrının benimsetilmesinde farkındalık oluşturmak için sesi ve kıraati ile öne çıkan ülkemiz hafızlarının görsel ve işitsel materyallerden yararlanılması hedeflenmiştir. Ayrıca, görsel ve işitsel olarak öğrencilerin harf talimi yapabilme, yüzünden okuyup dinleyebilme, ezberden dinleyebilme, anlamını öğrenebilme, görüntülü olarak sûre ve duaları dinleyebilme, tecvid uygulamalarının gerçekleştirilmesini bizzat bir fem-i muhsinden görebilme imkânı veren ve EBA'da yer alan "Kur'an-1 Kerim Dersleri İnteraktif Öğretim Materyali”nden yararlanılması istenmiştir.

Yine Kur'an öğretiminde temel bir metot olan arz ile öğrencilerin derse kat1lımının en üst düzeyde gerçekleştirilmesi amaçlanmıştır. Derslerin öğretiminde sevgi temelli bir yaklaşım sergilenmesi ve bireysel farklılıkların dikkate alınması vurgulanmış, küme çalışması ve işbirlikçi öğrenme yöntemleriyle öğrencilerin birbirlerine akran desteğinde bulunması hedeflenmiştir. Kur'an öğretiminin vazgeçilmez yöntem ve tekniklerinden olan koro çalışması ve bilhassa dudak talimine riayet edilmesi (müşâfehe, eda, gösterip yaptırma ve geri dönüt alma) vurgulanmış, hataların tashihinde kolaylaştırmaya fakat taviz verilmemesine dikkat çekilmiştir.

Kabiliyetli öğrencilerin teşviki hatırlatılmış, derslerin daha verimli işlenmesine katkı sağlaması açısından imkan dâhilinde özel dizayn edilmiş sınıfların 
oluşturulması tavsiye edilmiştir. Kur'an hattına dikkat çekilerek farklı hatlarla yazılmış Mushaflar'la ilgili (gözlem yoluyla) farkındalık oluşturulmak istenmiştir. Farklı düzeylerde okuma becerisi ile gelen veya hiç bilmeyerek gelenlere yönelik işbirliğine dayalı öğrenme, küme çalışması, taklit etme gibi yöntemlerden yararlanılması vurgulanmıştır.

Kur'an öğretiminde öğreticinin rolünü fark edecek şekilde öğretmenin mutlaka okuması (gösteri, model okuma) veya iyi bir okuyucudan dinleti yaptırmas1 (model gösterme, taklit) 1srarla vurgulanmış, bu bağlamda etkileşimli tahta, EBA içerikleri ve tabletlerden yararlanılması hatırlatılmıştır.

Yüzünden okumada, öğretmenin okumasının ardından öğrencilerin koro okuyuşu yapmaları istenerek Kur'an öğretiminin geleneksel metodu olan eda yöntemine dikkat çekilmiş, harflerin mahreçlerinden telaffuzunu kazandırmak için harf talimi yapılması istenmiştir. Model gösterme metoduyla öğrencilerin doğru ve güzel okuyuşu dinlemeleri, taklit ve tekrar yöntemleriyle de pekiştirmeleri hedeflenmiştir. Tecvitleri uygulama, anlam üzerinde düşünme ve yorumlama, bilgi teknolojilerini kullanma üzerinde durulmuştur.

Hâlen okutulmakta olan Kur'an-1 Kerim Dersi Öğretim Programı'nda 10. s1nıfta müstakil olarak verilen "Harflerin Mahreçlerinden Telaffuzu" konu başlığı altında harflerin üstün, esre, ötre, cezm, şedde ve med harfleriyle okunuşunu temin edecek kazanımlar verilmiş ve uygulanması istenmiştir. Öte yandan, Kur'an öğretim tekniği açısından önemli konuların programda ayrıntılarıyla yer alması yanı sıra kıraat ile ilgii temel kavramlar arasında fem-i muhsin, dudak talimi ve mehâric-i huruf kavramlarının müstakil olarak işlenmesi de olumlu bir gelişme olarak görülebilir.

2016 y1lından itibaren hâlen yürürlükte olan programı incelendiğinde dersin öğretim yöntem ve tekniklerinin ana hatları ile yer aldığı, ancak "etkinlikler" bakımından bir önceki programdaki kadar zengin olmadığı görülecektir. 2008 yılında hazırlanan öğretim programında "Etkinlik Örnekleri”, "Açılamalar”, "Öğretim Programı Örnek Etkinlik Uygulamaları" başlıkları altında genişçe yer verilen yöntem ve teknikler 2016 yılında hazırlanan programda "Programın Uygulanmasına İlişkin İlke ve Açıklamalar” bölümü ile kazanımlarla ilgili “Açıklamalar" bölümünde ana hatlarıyla verilmiştir. Ancak, 2016 yılından itibaren uygulanan Kur'an-1 Kerim dersi öğretim programının öğretim yöntem ve teknikleri bakımından bir önceki programdan temel bir farkı da bulunmaktadır. 1984 yılında hazırlanan ve 1999 yılına kadar okutulan öğretim programında kısmen yer alan “Kur'an Öğretiminde Metot” bölümü programda 10. sınıf dü- 
zeyinde "Kur'an Öğretiminde Temel İlke ve Yöntemler" adıyla müstakil bir ünite olarak yer almıştır. Bu müstakil ünite Tablo 2'de sunulmuştur.

Tablo 2: Kur'an Öğretiminde Temel İlke ve Yöntemler

\begin{tabular}{l} 
1. Temel İlkeler \\
\hline 1.1.Tilavette Asla Uygunluk \\
1.2.Fem-i Muhsin'den Öğrenmek \\
1.3.Harfleri Doğru Telaffuz Etmek \\
1.4.Tecvid Kurallarına Uygun Okumak \\
1.5.Tefekkür ve Tedebbüre Dikkat Etmek \\
1.6.Sevgi Temelli Yaklaşım \\
2. Temel Yöntemler \\
\hline 2.1. Semâ' \\
2.2. Arz \\
2.3. Edâ \\
2.4.Koro Çalışması Yapmak \\
2.5.Harf Talimi Yapmak/Yaptırmak \\
2.6.Tecvid Öğretiminde Teori ve Uygulama Birlikteliği
\end{tabular}

Tablo 2 incelediğinde Kur'an öğretiminde öğretmenin riayet etmesi gereken temel ilke ve yöntemler bizzat dersin muhtevası yapılmış, hem öğretmenin Kur'an öğretiminin nasıl yapılacağını öğretmesi hem de bu süreçte öğretmenlerin bir metodu, yöntemi ve temel ilkeleri uygulayarak öğrencilere göstermesi ve benimsemesi hedeflenmiştir denilebilir.

2008 yılında hazırlanan öğretim programda uygulama esaslarında ve öğretim etkinliklerinde genişçe yer verilen yöntem, teknik ve materyal kullanımına dair uygulamalar ağırlıklı olarak 2016 yılında uygulamaya konulan bu ünitede daha sistemli bir şekilde bir metot dâhilinde verilmiştir. Bu durum programın uygulayıcıları için de bir zorunluluk oluşturmuş doğrudan Kur'an öğretmenlerinin bu ilke ve yöntemleri okumasını ve okutmasını sağlayarak bilgi ve beceriler edinmelerini sağlamıştır. Aynı zamanda öğrencilerin de bu metotları görüp işitme ve uygulamanın bir bileşeni olmaktan ziyade Kur'an öğretim yöntemlerini ana hatlarıyla bilimsel olarak öğrenmesine katkı sağlaması da sağlanmıştır. Ancak, bu bölüm, Kur'an-1 Kerim dersinin uygulama esaslarında yer almamış, müfredatın tamamını esas alacak şekilde kurgulanmayarak sadece 10. sınıf II. ünitede dersin içeriği olarak konulmuştur. Bu bölümün sadece 10. sınıfta olması nedeniyle bu sınıf düzeyindekilere ders okutmayan öğretmenler bu ünitedeki konulara vâkıf olamayabilecektir.

Kur'an-1 Kerim dersi müfredat/öğretim programlarının tamamı göz önünde bulundurulduğunda süreç içerisinde dersin konu ve kazanımlarında artış olurken uygulamayla ilgili açıklamalar kısmında da yöntem ve tekniklerin ilave 
edildiği görülmüştür. Ancak müfredatın muhtevasında lafız-anlam bağlamında zaman zaman artma veya azalma görülürken, yöntem ve teknik bağlamında süreç odaklı yükselen bir ivme olduğu söylenebilir. Örneğin; 1984 y1lında hazırlanan öğretim programında lafız yönü ağırlık kazanırken, 1999 yılında hazırlanan programda anlam öğretimi ağırlık kazanmıştır. Öğretim yöntemleri açısından ise son iki programın (2008 ve 2016) önceki programlara nazaran yenilikler içerdiği tespit edilmiştir. Nitekim Tablo 3 'te bu durum gösterilmiştir. 1924 yılında İmam ve Hatip Mektepleri için hazırlanan müfredat programları ile 2016 yılında hazırlanan son öğretim programına kadar bütün programlarda Kur'an öğretimin temel yöntemlerinden sema' ve arzın yer aldığ da edâ, model gösterme, takrir, tekrar ve buldurma yöntemlerinin öne çıktığ1 görülmüştür.

\section{Müfredat/Öğretim Programlarında Yer Alan Öğretim Yöntem ve Tekniklerin Uygulama Düzeyine İlişkin Bazı Verilerin Değerlendirilmesi}

Müfredat/öğretim programlarının tamamı göz önünde bulundurulduğunda Kur'an öğretiminin özel yöntemlerinden sema', arz ve edâ başta olmak üzere belirli oranda yöntem ve tekniklerin yer aldığı söylenebilir. Ancak, dersin özel öğretim yöntem ve tekniklerinin geliştirilmesine ihtiyaç olmakla beraber en önemli hususun bu yöntemlerin uygulanmasıyla ilgili hususların üzerinde durulması gerekmektedir. Bu bağlamda, Kur'an-1 Kerim dersinin niteliğini artırmak için öncelikli olarak öğretmenlerin meslekî yeterliliğinin (kârî ve mukrî olması) sağlanması elzemdir.

Nitekim, Kur'an-1 Kerim öğretmeni, en başta icrac1, yani teorik bilgileri bir taraftan öğretirken diğer taraftan onları en doğru ve en güzel biçimde seslendirmek suretiyle uygulayıcı konumundadır. Kur'an öğretmeni ayetleri oluşturan harfleri, kelimeleri ve cümleleri bizzat okuyarak, gerektiğinde tekrar yaparak Kur'an dersini hem nazari hem de tatbiki bir çerçevede yürüten bir eğiticidir (Çollak, 2005, s. 133-134).

Kur'an öğretiminde ders öğretmeninin sadece Kur'an-1 Kerim'i kural ve kaidelerine uygun biçimde okuması yeterli değildir. Dersin genel ve özel amaçları çerçevesinde öğretim programında belirtilen muhtevanın öğrencilere kazandırılabilmesi, dersin öğretimine dair özel öğretim yöntem ve tekniklerinin bilinmesi ve uygulanmasıyla mümkündür. Bu nedenle, derslerin öğretim programlarında dersin uygulanmasına yönelik açıklamalara yer verilmekte ve ısrarla öğretmen- 
lerden bu uygulamaları yerine getirmeleri istenmektedir. Bu açıdan bakıldığında, İHL meslek dersleri öğretmenleri üzerinde yapılan bir araştırmada da öğretmenlerin çoğunun -teorik bilgiler ve pratik uygulamalar açısından- kendilerini belli noktalarda istenen düzeyde görmedikleri; kendileri için bu minvalde yöntem ve teknik becerilerinin artırılmasına yönelik destek programlarının düzenlenmesinin gerekli olduğu belirtilmesi dikkat çekmektedir (Kıliç, 2015, s. 103).

Daşkın tarafından yapılan araştırmada öğretmenlerin dersin öğretim yöntem ve teknikleri kullanma becerisi üzerine durulmuş; öğretmenlerin konuların özelliğine göre yöntemleri tercihte gerekli şekilde hassasiyet göstermediği, derste izleyecekleri yöntemlerle ve araç gereçlerle ilgili önceden hazırlık yapmadıklar1, ilk öğrenme, yüzünden ve ezbere okumada benzer metotları ve genellikle de geleneksel yöntemleri kullandıkları, yeni yöntem arayışına ve kullanımına gitmedikleri gözlemlenmiştir (Daşkın, 2007, s. 92). Korkmaz tarafından yapılan araştırmada İHL'lerde görev yapan meslek dersleri öğretmenlerine yönelik yeni çalışmalarla derse ait özgün öğretim materyalleri, kılavuz kitaplar ve hizmet içi eğitim faaliyetleri ile öğretmenlere bilgi, beceri ve kaynak desteği sağlanması gerektiği önerilmektedir (Korkmaz, 2017, s. 534-535).

İstanbul'da Ensar Vakfı (2011) tarafından gerçekleştirilen çalıştayda İmam hatip liselerinden mezun öğrencilerin imamlık, müezzinlik, Kur'an Kursu öğreticiliği yeterlik sınavlarındaki başarı düzeylerinin düşük olduğu; imam hatip meslek dersi öğretmenlerinin mesleki yetersizliğinin bulunduğu; dersin özel öğretim yöntem ve tekniklerinin öğretmenler tarafından bilinmediği ve uygulanmadığ1; yeterli ve özgün öğretim materyallerinin geliştirilmediği yönünde görüşler ifade edilmiştir. İstanbul İl Millî Eğitim Müdürlüğü (2011) tarafindan İHL Meslek Dersleri öğretmenleri ile yapılan çalıştay sonucunda hazırlanan raporda İHL'lerde Kur'an dersine giren öğretmenler, klasik Kur'an öğretim yöntemlerinin bilindiğini fakat yeni uygulamaların bilinmesine de ihtiyaç duyulduğunu belirtmişlerdir.

Farklı zaman dilimlerinde yapılan bazı araştırmalardan hareketle öğretim programındaki yöntem ve teknikleri uygulamada öğretmenlerin meslekî yeterliliklerinin geliştirilmesi gerektiği söylenebilir. Bu bağlamda yeni araştırmalar yapılmasına ihtiyaç duyulmakta olup burada konuyla ilgili birkaç örnek verilmekle yetinilecektir.

23-25 Nisan 1981 yılında gerçekleştirilen I. Din Eğitimi Semineri'nde sunulan tebliğcilerden bazıları tarafından İHL mezunlarının Kur'an okuma becerilerinin oldukça zayıf olduğu, hatta bir kısmının Fatiha Sûresi’ni dahi doğru dürüst 
okuyamadığ belirtilmiştir. Bu eksikliğin giderilmesi için de Diyanet İşleri Başkanlığı'nca 3-5 aylık hizmet içi eğitim kursları açıldığı, burada da bazı öğrencilerin istenen seviyeye gelemediği ifade edilmiştir (Topcuk, 1995, s. 27-28).

1994-1995 Öğretim y1lında Türkiye'deki 76 ildeki farklı İHL'lerden mezun olup Ankara, İzmir Dokuz Eylül ve Konya Selçuk Üniversitesi İlahiyat Fakültelerinde eğitim gören 464 öğrenci üzerinde uygulanan ankette öğrencilere öğretmenlerinin Kur'an dersinde örnek okuyuş yapıp yapmadıkları sorulmuş ve \%21,34'ü hiç okuma yapmadığını, \%49,57'si ise bir kısmının okuma yaptığını belirtmiştir. Yine öğretmenlerini sınıfta okuyup tekrar etmesi durumu sorusuna öğrencilerin \%33, 84'ü hiçbiri, \%45,69'u bir kısmı cevabını vermiş̧ir (Topcuk, 1995, s. 58-59). Halbuki öğretim programında yer alan “Kur'an Öğretiminde Tekrarın Önemi, Kur'an Öğretiminde Ses ve Kulak Terbiyesi, Kur'an'1 Tecvid Kurallarına Göre Okuma ve Sonra Kuralları Söyleme" metotlarına, yöntem ve tekniklerine riayet edilse durum daha farklı olabilirdi. Nitekim aynı araştırmada öğretmenlerin örnek okuyuş yapıp yapmamalarına göre başarı ortalamalarının farklı olduğu görülmüştür. Öğretmenleri örnek okuyuş yaptığını belirten 135 öğrencinin (\%29) başarı ortalamasının öğretmenleri örnek okuyuş yapmayan 329 öğrenci (\%71) den daha yüksek olduğu görülmüsstür (Topcuk, 1995, s. 77).

Sivas ili ve ilçelerindeki okullarda yapılan bir alan araştırmasında öğretmenlerin $\% 8,8$ 'i ilk sırada programın gerçekleşmemesinin sebebi olarak öğretmenlerin öğretim yöntemleriyle ilgili yetersizliklerini, \%7'si de yine birinci sırada araç, gereç ve kaynak eskikliği olduğunu belirtmiştir (Kantar, 2008, s. 69). Aynı araştırmada öğretmenlerin büyük çoğunluğu dersin amaçlarının gerçekleştirilemediğini ve bunun gerekçeleri arasında "öğretim yöntem ve tekniklerindeki yetersizlikleri ile araç gereç ve kaynak eksikliği”" olduğunu belirtmiştir (Kantar, 2008, s. 97).

Aynı dönem Erzurum ilindeki İHL'lerde görev yapan İHL Meslek Dersleri öğretmenlerinin \%75,8'inin takrir (anlatım) metodunu, \%18,2'sinin ise soru-cevap metodunu kullanıyor olması az bir kısmının diğer metodlardan yararlandığını belirtmesi Sivas ilinde gerçekleştirilen araştırmayı teyid eder mahiyattedir (Taş̧̧1, 2006, s. 51). Programda ne kadar da yöntem teknik vurgusu artmış olsa da kazanımların gerçekleşmemesinde öğretmenlerin yöntem, teknik bilgi ve becerilerinin olmadığı, bu konuda gerekli eğitim almadıkları ve bir farkındalığın bulunmadığı ön plana çıkmaktadır. 2009 yılında farklı illerde görev yapan 216 öğretmenin katıldığı bir alan araştırması sonuçlarına göre İHL'lerde uygulanan yeni öğretim programlarının temel yaklaşımı ve yapısı, öğretmenlerin büyük 
çoğunluğu tarafından beklenen düzeyde incelenip anlaşılmadığını ve uygulanmadığını belirtmiştir (Koç, 2009, s. 170).

Bayburt ilindeki 179 İmam Hatip Ortaokulu, 194 İHL öğrencisinin okuyuşlarının kaydedilerek öğrencilerin harflerin mahreçlerine ve tecvid kurallarına uygun olarak doğru ve güzel okuma yeterliliğine sahip olup olmadıklarını ölçmek için yapılan bir araştırma sonuçlarına göre derslerde harf talimine yönelik çalışmaların yeterli seviyede olmadığ telaffuz edemedikleri, cezimli harfleri harekelendirerek sarstıkları, dudak talimi bakımından yetersiz oldukları, peltek harfleri ve kalın harfleri mahreçlerinden çıkaramadıkları, Kur'an okuma biçimlerinin yeterince kavratılamadığı gözlemlenmiştir (Kaya ve Topyay, 2019, s. 444-445).

Öğretmenlerin Kur'an tilâveti ve öğretim yöntemleri alanındaki meslekî gelişimleri bağlamında ise, 2014 y1lında İstanbul'da Anadolu yakasındaki İmam Hatip Liselerinde ve İmam Hatip Ortaokullarında görev yapan 214 öğretmen üzerinde Kılıç tarafından yapılan araştırmada dikkat çeken veriler bulunmaktadır. Araştırmaya göre öğretmenlerin \%85,1'i okullarda verilen Kur'an eğitim seviyesinden memnun olmadıklarını, yine kanaatlerine göre Kur'an derslerinde alanında uzman bir hocanın sınıf başarısına katkısının \%77,7 olduğunu, "Tecvid, mahreç ve telaffuz konularının teorik bilgilerinde eksikliğiniz olduğunu düşünüyor musunuz" sorusuna öğretmenlerin \%72,3'ünün belirtilen hususlarda eksiklerinin olduğunu "Tecvid, mahrę̧ ve telaffuz konularının pratikte uygulanması noktasında eksiklerinizin olduğunu düşünüyor musunuz? " sorusuna ise \%69,8'i "Evet" cevabıyla bazı eksiklerinin olduğunu ifade etmiştir. Araştırmada ortaya çıkan daha ilginç bir husus ise öğretmenlere bu kurumlardaki Kur'an eğitiminin daha iyi bir seviyede olması için meslektaşlarının tilâvet konusunda yetkin bir hocadan talim (tecvid ve tashih-i huruf) dersleri almalarının gerekliliğinin olup olmadığı sorulmuş ve öğretmenlerin \%90,9’u “Evet, buna ihtiyaç olduğınu düşünüyorum” derken \%7,4'ü ihtiyaç olmadığını düşündüğünü belirtmiş, \%1,7'si de soruyu cevapsız bırakmıştır. Ankete katılan öğretmenler de ilahiyat fakültelerindeki öğrencilikleri esnasında aldıkları Kur'an derslerinin bu dersin hocalığını yapabilmek için kendilerine yeterli gelmediğini, alanında uzman bir hocadan yine ders almaya ihtiyaç duyduklarını belirtmişlerdir. Yine pek çok katılımcı da Kur'an öğretim yöntem ve teknikleri bağlamında öğretmenlere seminerlerin düzenlenmesi gerektiğini ifade etmişlerdir. (Kılıç, 2014, s. 92-94). 


\section{Sonuç ve Öneriler}

İmam Hatip Okullarına yönelik 1924'ten günümüze kadar belirli dönemlerde hazırlanan ve uygulamaya konulan Kur'an-1 Kerim dersi müfredat/öğretim programlarında dersin özel öğretim yöntem ve tekniklerin yer almasında süreç içerisinde olumlu gelişmeler olmuştur. Özellikle 1984 ve sonrası hazırlanan programlarda yöntem bilgisine daha çok önem verildiği görülmüştür.

1924-1933 y1llarında okutulan müfredat programında sema', arz, takrir ve tekrar yöntemleri yer almıştır. 1951-1965 yılları arasında okutulan müfredat programında dersin öğretim yöntem ve tekniklerine dair bilgilere yer verilmeyip sadece Kur'an-1 Kerim'in tecvid kaidelerine göre sema' ve arz yöntemi ile okutulması ve bazı sûrelerin ezber yaptırılması üzerinde durulmuştur. 1965 y1lında hazırlanan müfredat programında biraz ilavelerle sema' arz, edâ ve model gösterme yöntemlerine yer verilmiştir. Aynı müfredat programı üzerinde 1972 yılında güncellemeler yapılmış ve ilâve olarak sadece yaparak ve yaşayarak öğrenmeye dikkat çekilmiştir.

Kur'an-1 Kerim dersi öğretim yöntem ve teknikleri ayrıntılı olarak ilk defa 1984 yılında "öğretim programı" adıyla hazırlanan programda yer almıştır. Öğretim programında sema', arz, edâ, model gösterme, takrir, tekrar, bireysel çalışma, buldurma yöntem ve tekniklerinin uygulanması talep edilmiştir. 1999 yılında uygulamaya konulan öğretim programında sem'a, arz, edâ, model gösterme, koro çalışması, takrir, tekrar, beyin firtınası, buldurma, soru-cevap yöntem ve tekniklerine dersin öğretiminde başvurulması istenmiştir.

2008 yılında hazırlanan programda önceki yıllardakine nazaran yöntem ve tekniklere daha ayrıntılı yer verildiği görülmüştür. Söz konusu programda sema', arz, edâ, soru-cevap, küme çalışması, toplu okutma (koro çalışması), takrir, taklit etme, tekrar, problem çözme, model gösterme, gözlem, buldurma, rol yapma, bireysel çalışma, beyin firtınası, eğitsel oyun, işbirliğine dayalı öğrenme, küçük grup tartışması ve panel yöntem ve teknikleri yer almıştır. 2016 y1lından itibaren uygulanan öğretim programının bir önceki programdaki detayları ihtiva etmese de yeterli yöntem ve teknikleri içerdiği görülmüştür. Programda, sema', arz, edâ, model gösterme, takrir, tekrar, buldurma, soru-cevap, beyin firtınası, küçük grup tartışması, taklit etme, problem çözme, işbirliğine dayalı öğrenme, küme çalışması ve gözlem yöntem ve teknikleri yer almıştır. Kur'an öğretiminde temel ilke ve yöntemlerin müstakil bir ünitede bulunmas1 bu program için önemli bir gelişme olarak değerlendirilebilir. 
Tablo 3: 1924-2016 Yılları Arsındaki Müfredat/ Öğretim Programlarında Yer Alan Yöntem ve Teknikler

\begin{tabular}{|c|c|c|c|c|c|c|c|c|}
\hline Yöntem ve Teknikler & $\begin{array}{l}1924- \\
1933\end{array}$ & $\begin{array}{l}1951- \\
1965\end{array}$ & $\begin{array}{l}1965- \\
1972\end{array}$ & $\begin{array}{l}1972- \\
1984\end{array}$ & $\begin{array}{l}1984- \\
1999\end{array}$ & $\begin{array}{l}1999- \\
2008\end{array}$ & $\begin{array}{l}2008- \\
2016\end{array}$ & $\begin{array}{l}2016 \\
\text { ve son- } \\
\text { rasi }\end{array}$ \\
\hline $\begin{array}{l}\text { Sema' (Gösteri - Model } \\
\text { Okuma) }\end{array}$ & $\mathrm{x}$ & $\mathrm{x}$ & $\mathrm{x}$ & $\mathrm{x}$ & $\mathrm{x}$ & $\mathrm{x}$ & $\mathrm{x}$ & $\mathrm{x}$ \\
\hline Arz (Gösterip Yaptırma) & $\mathrm{x}$ & $\mathrm{x}$ & $\mathrm{x}$ & $\mathrm{x}$ & $\mathrm{x}$ & $\mathrm{x}$ & $\mathrm{x}$ & $\mathrm{x}$ \\
\hline $\begin{array}{l}\text { Edâ (Gösterip Yaptırma ve } \\
\text { Geri Dönüt Alma) }\end{array}$ & & & $\mathrm{x}$ & $\mathrm{x}$ & $\mathrm{x}$ & $\mathrm{x}$ & $\mathrm{x}$ & $\mathrm{x}$ \\
\hline Model Gösterme & & & $\mathrm{x}$ & $\mathrm{x}$ & $\mathrm{x}$ & $\mathrm{x}$ & $\mathrm{x}$ & $\mathrm{x}$ \\
\hline Takrir (Anlatım) & $\mathrm{x}$ & & & & $\mathrm{x}$ & $\mathrm{x}$ & $\mathrm{x}$ & $\mathrm{x}$ \\
\hline Tekrar & $\mathrm{x}$ & & & & $\mathrm{x}$ & $\mathrm{x}$ & $\mathrm{x}$ & $\mathrm{x}$ \\
\hline Buldurma & & & & & $\mathrm{x}$ & $\mathrm{x}$ & $\mathrm{x}$ & $\mathrm{x}$ \\
\hline $\begin{array}{l}\text { Taklit Etme/Rol Yapma } \\
\text { (Dramatizasyon) }\end{array}$ & & & & & & & $\mathrm{x}$ & $\mathrm{x}$ \\
\hline Soru-Cevap & & & & & & $\mathrm{x}$ & $\mathrm{x}$ & $\mathrm{x}$ \\
\hline Gözlem & & & & & & & $\mathrm{x}$ & $\mathrm{x}$ \\
\hline Tartışma & & & & & & & $\mathrm{x}$ & $\mathrm{x}$ \\
\hline Problem Çözme & & & & & & & $\mathrm{x}$ & $\mathrm{x}$ \\
\hline Bireysel Çalışma & & & & & $\mathrm{x}$ & & & $\mathrm{x}$ \\
\hline Küme Çalışması & & & & & & & $\mathrm{x}$ & $\mathrm{x}$ \\
\hline Eğitsel Oyun & & & & & & & $\mathrm{x}$ & \\
\hline Koro Çalışması & & & & & & $\mathrm{x}$ & $\mathrm{x}$ & $\mathrm{x}$ \\
\hline $\begin{array}{l}\text { Yaparak ve Yaşayarak } \\
\text { Öğrenme }\end{array}$ & & & & $\mathrm{x}$ & & & $\mathrm{x}$ & \\
\hline İşbirliğine Dayalı Öğrenme & & & & & & & $\mathrm{x}$ & $\mathrm{x}$ \\
\hline Beyin Fırtınası & & & & & & $\mathrm{x}$ & $\mathrm{x}$ & $\mathrm{x}$ \\
\hline Panel & & & & & & & $\mathrm{x}$ & \\
\hline
\end{tabular}

Dersin öğretim yöntem ve tekniklerine dair olumlu gelişmeler görülmüştür. Ancak, programın kazanımlarının gerçekleştirilmesi için öğretmenlerin mesleki yeterliliği önemli bir yere sahiptir. Kur'an öğretiminde temel sorunun ve niteliğine dair tartışmaların müfredattan ve kitaptan ziyade, öğretim programında ve kitaplarda belirtilen yöntem ve tekniklerin ehliyetli ve liyakatli öğretmenler tarafindan uygulanmasıyla doğrudan ilişkili olduğu söylenebilir. Kur'an öğretiminde kârî ve mukrî vasfina sahip, dersin özel öğretim yöntemlerini bilen ve uygulayan, bu alanda özel bir eğitim sürecinden geçen öğretmenlerin lüzumu bütün Kur'an eğitimcilerinin ittifak ettiği bir konudur.

Yapılan bu araştırma, Kur'an-1 Kerim dersi öğretim programlarının ihtiva ettiği öğretim yöntem ve tekniklerin tespitine yönelik bir çalışmadır. Mevcut öğretim programında belirtilen ve ders kitaplarında yer alan yöntem, teknik ve materyal kullanımına dair hususların ne derecede uygulamaya yansıdığg ise bir başka araştırmanın konusu olarak ele alınmalıdır. Öğretim programında yer 
alan kazanımların istenen düzeyde gerçekleşmesi, öğrencilerin hazırbulunuşluklarına ve beklentilerine göre Kur'an eğitimi verilebilmesi için geleneksel ve yaygın yöntemlere ilaveten yeni yöntem ve tekniklerin neler olabileceği ve bunların nasıl uygulanacağı üzerinde çalışmalar yapılmalıdır. Türkiye'de, İslam ülkelerinde ve Müslüman toplulukların yaşadığı ülkelerde Kur'an öğretiminde yöntemler ve materyal kullanımına dair karşıllaştırmalı akademik araştırmalar yapılmalidir.

\section{Kaynakça}

Albayrak, H. ve Serinsu, A. (2004). İmam hatip liseleri hazırlık sinıfi Kur'an-ı Kerim. Millî Eğitim Bakanlığı.

Annadıç, İ. (2019). İmam hatip mektepleri meslek dersleri ögretim programlart ve bu programlarin hazırlanmasinda etkili olan anlayışlar (1924-1930) (Yayımlanmamış yüksek lisans tezi). Ankara Yıldırım Beyazıt Üniversitesi Sosyal Bilimler Enstitüsü.

Aşıkoğlu N. Y. (2010) Kur'an öğretiminde yeni anlayış ve yaklaşımlar, Etkili Din Öğretimi, ed. Şaban Karaköse.TIDEF, ss. 549-560.

Aydın, M. Z. (2010) Din öğretimi yöntemleri, Etkili Din Öğretimi, ed. Şaban Karaköse, 2. b.,TIDEF, ss. 281-304.

Biceğez, Y. (2017), Kur'an ögretiminde ilkeler, yöntem ve teknikler (Yayımlanmamış yüksek lisans tezi). Necmettin Erbakan Üniversitesi Sosyal Bilimler Entitüsü, Konya.

Çollak, F. (2005). Kur'an-ı Kerim dersi müfredatı ve ögretim teknikleri, İmam Hatip Liselerinde Eğitim ve Öğretim Sempozyum Bildirileri, Ed: Zengin, M., İstanbul:Dem Yayınları, ss. 125-136.

Daşkın, A. (2007). Imam Hatip Liselerinde Kur'an-ı Kerim Derslerinde İzlenen Yöntemler (Yayımlanmamış yüksek lisans tezi). Erciyes Üniversitesi Sosyal Bilimler Enstitüsü, Kayseri.

Döğen, H. (1992). Tevhid-i Tedrisat Kanunu ve Imam Hatip Mektepleri (Yayımlanmamış yüksek lisans tezi) Uludağ Üniversitesi Sosyal Bilimler Enstitüsü.

Ensar Vakfı. (2011). Kur'an ve Kıraat Eğitimi Müfredat Çalıştayı Müzakereleri, İstanbul.

İstanbul İl Millı̂ Eğitim Müdürlüğü. (2011). İmam Hatip Liseleri Meslek Dersleri Çalıştay Sonuçları, İstanbul: Mesleki Eğitim Merkezi (MESBİL).

Kantar, H. (2008). İmam Hatip Liselerinde Kur'an-ı Kerim Öğretimi Üzerine Bir Değerlendirme (Sivas Örneği) (Yayımlanmamış yüksek lisans tezi) Cumhuriyet Üniversitesi Sosyal Bilimler Enstitüsü. Sivas. 
Kaya F. ve Topyay Y. (2019). Imam hatip ortaokul ve liselerindeki Kur'an-ı Kerim ögretimin ögrenciler açısından değerlendirilmesi (Bayburt Örneği). Geleceğin İnşasında İmam Hatip Okulları Sempozyumu Bildirisi, ed. İlhan Erdem vd., Malatya: İnönü Üniversitesi, ss. 431-446.

Kılıç, M. (2014). İmam Hatip Ortaokul ve Liselerinde Kur’ân Eğitimi Üzerine Bir Araştırma. Marmara Üniversitesi İlâhiyat Fakültesi Dergisi, C.S. 47, 69-106.

Korkmaz, M. (2017). Imam hatip lisesi meslek dersleri ögretmenlerinin öğretim araç ve materyallerinden yararlanma durumu, Geleceğin İnşasında İmam Hatip Okulları Sempozyumu Bildirisi, ed. İlhan Erdem vd., Malatya: İnönü Üniversitesi, ss. 517-536.

Koç, Ahmet. (2009). İmam hatip lisesi meslek dersleri öğretmenlerinin yeterlikleri üzerine bir araştırma. Cumhuriyet Üniversitesi Illahiyat Fakültesi Dergisi C. 13, S. 2, ss 131-174.)

MEB. (1951). Talim ve Terbiye Dairesi’ İmam Hatip Okullarının Ders Dağıtım Cetveli Hk. 20 Kasım 1951 Tarihli 184 Nolu Kararı. (MEB Talim ve Terbiye Kurulu Başkanlığından 11.05.2020 tarihli e-posta ile alınan bilgi)

MEB. (1952). Talim ve Terbiye Dairesi’ İmam Hatip Okulları Birinci Devre Müfredat Programları Hk, 11 Ocak 1951 Tarih ve 3 Sayılı Kararı.

MEB. (1953). Talim ve Terbiye Dairesi’, 27 Ekim 1953 tarih ve 257 Sayılı Karar.

MEB. (1954). Talim ve Terbiye Dairesi’ İmam Hatip Okulları İkinci Devre Müfredat Program, 1 Ekim 1954 Tarih ve 190 Sayılı Kararı.

MEB. (1955). Talim ve Terbiye Dairesi’ İmam Hatip Okulları İkinci Devre Müfredat Program Hk., 1 Ekim 1955 Tarih ve 213 Sayılı Kararı.

MEB. (1965). Talim ve Terbiye Dairesi', 8 Ekim 1965 tarih ve 181 sayılı Kararı ile kabul Edilen İmam Hatip Okulları Müfredat Programı.

MEB. (1972a). Tebliğler Dergisi, C. 35, S. 1699, Mayıs 1972, s. 175.

MEB. (1972b) Tebliğler Dergisi, C.35, S. 1708, Temmuz 1972, s. 247-252.

MEB. (1972c). Tebliğler Dergisi, C. 35, S. 1724, Aralık 1972, s. 434.

MEB, (1973a). Millî Eğitim Temel Kanunu, Ankara, 1973 https://www.mevzuat. gov.tr/MevzuatMetin/1.5.1739.pdf

MEB. (1973b). Tebliğler Dergisi, C. 36, S. 1750, Ankara, 2 Temmuz 1973, s. 283.

MEB. (1973c). Talim ve Terbiye Dairesi', 12 Temmuz 1973 Tarihli 437 Sayılı Karar1.

MEB. (1978). Talim ve Terbiye Dairesi’nin 02.01.1978 Tarih ve 1 Sayılı Kararı.

MEB. (1983) Talim ve Terbiye Daire Başkanlığı 11.10.1983 tarih ve 177 Sayılı Karar. (Tebliğler Dergisi, c. 46, s. 2147-2151) 
MEB. (1984). Talim ve Terbiye Kurulu Başkanlığı'nın 18.10.1984 Tarih ve 143 Sayılı Kararı.

MEB. (1985). Din Öğretimi Genel Müdürlüğü, İmam Hatip Liseleri Öğretim Programlar1.

Ankara: Millî Eğitim Basımevi, ss.1-268.

MEB. (1998). Tebliğler Dergisi, C. 61, S. 2492, Ankara.

MEB. (1999a). Tebliğler Dergisi, C. 62, S. 2501, Ankara.

MEB. (1999b). Din Öğretimi Genel Müdürlüğü İmam Hatip Lisesi, Anadolu İmam Hatip Lisesi, Yabancı Dil Ağırlıklı İmam Hatip Lisesi, Meslek Dersleri Öğretim Programları. Ankara: Milli Eğitim Basımevi.

MEB. (2005). Tebliğler Dergisi, C. 68, S. 2579, Ankara.

MEB. (2008a). Din Öğretimi Genel Müdürlüğü İmam Hatip ve Anadolu İmam Hatip Lisesi Meslek Dersleri Öğretim Programları. Ankara: Millî Eğitim Bakanlığı.

MEB. (2008b). Tebliğler Dergisi, C. 69, S. 2588, Ankara.

MEB. (2010). Talim ve Terbiye Kurulu Başkanlığı 20.07.2010 tarih ve 76 sayılı Karar1.

MEB. (2016). Tebliğler Dergisi. C. 79. S. 2705, s. 345, Ankara.

MEB. (2017). Tebliğler Dergisi. C. 80. S. 2717, s. 156, Ankara.

MEB. (2020). Eğitim Bilim Ağı. Erişim adresi: http://www.eba.gov.tr/ kuranuygulamasi

MEB DÖGM. (2015). İHL Meslek Dersleri Öğretmen Yeterlilikleri.

http://dinogretimi.meb.gov.tr/meslekigelisim/IHLMeslekDersleriYeterlikleri.pdf

MEB DÖGM. (2019) İHL Öğrenci Yeterlilikleri.

http://dinogretimi.meb.gov.tr/meslekigelisim/AIHLOgrenciYeterlikleri.pdf

Öcal, M. (2013). 100. Yılında İmam Hatip Liseleri. İstanbul: Ensar Yayınları.

Öcal, M. (2017). Osmanlı'dan günümüze Türkiye'de din eğitimi. İstanbul: Dergâh Yayınları.

Öcal, M. (2019). Kuruluşundan bugüne din öğretimi genel müdürlüğü ve genel müdürler (1961-2015). İstanbul: Ensar Neşriyat.

Pakdil, R. (2017). Ta'lim, Tecvid ve Kıraat, İstanbul: İFAV Yayınları.

Salman, F., Y1lmaz, N. ve Morgül N. (2004). Imam Hatip Liseleri Meslek Dersleri Öğretim Programları Çalışma Raporu (Kur'an-1 Kerim Dersi). (Komisyon Raporu) İstanbul: Değerler Eğitimi Merkezi. 
Sarı, M. A. (2011). Kur'an-1 Kerim'i Güzel Okuma Tekniği ve Kuralları. İstanbul: İFAV Yayınları.

Taşc1, C. (2006). Imam Hatip Liselerinde Meslek Dersi Öğretiminin Yeterlik Durumu ve Meslek Dersleri Ögretmenlerinin Temel Yeterliklere Sahip Olma Düzeyleri (Yayımlanmamış yüksek lisans tezi) Atatürk Üniversitesi Sosyal Bilimler Enstitüsü. Erzurum.

Tetik, Necati. Kur'an Tilâvetinin veya Kıraat İlminin Öğretilmesi Usûllleri, Erzurum: Atatürk Üniversitesi İlahiyat Fakültesi Dergisi, S.9, 1990, ss. 238-244.

Topcuk, A. (1995). İmam Hatip Liselerindeki Kur'an-ı Kerim Öğretiminin Verimliliği (Yayımlanmamış yüksek lisans tezi). Dokuz Eylül Üniversitesi Sosyal Bilimler Enstitüsü. İzmir.

Tunç, M. V. (2019). Kuruluşundan Günümüze İmam Hatip Okullarının Programları ve Eğitim Yaklaşımları, (Yüksek lisans tezi), Erzurum: Atatürk Üniversitesi Sosyal Bilimler Enstitüsü.

Yılmaz, N. (2016). Kur’an-1 Kerim'i Nasıl Öğretelim, İstanbul: DEM Yayınları. 
Extended Abstract

\section{An Assessment on Methods and Techniques in the Curricula of the Course of Quran for Imam Hatip High Schools (1924-2016)}

Nazif YILMAZ, Corresponding Author, Ph. D. Student.

Republic of Turkey Ministry of National Education, General Management of Religious Education,

Ankara/Turkey.

nazifyilmaz@gmail.com

https://orcid.org/0000-0003-4701-5763

Article Type: Research Article

https://doi.org/10.34234/ded.816323

Received Date: 26.10 .2020

Accepted Date: 09.12 .2020

Published Date: 25.06.2021

\section{Introduction}

Imam Hatip High Schools are leading institutions in the field with regards to Quran instruction and religious teaching. The course of Quran is the main course within the core curriculum at these schools. In practice of profession regarding the fields of religious teaching and religious services, the basic competence that is needed is recitation of Quran. Hence, in Ministry of National Education "Special Field Competencies for Vocational Courses Teachers at Imam Hatip High Schools"- the competencies like; Quran recitation, reciting certain surahs for teachers; and the competencies on developing skills of proper and smooth Quran recitation, comprehension and interpretation for students- have been included (MoNE [Ministry of National Education] DgfRT [Directorate General for Religious Teaching] IHHSs [Imam Hatip High Schools] Teacher Competencies For Vocational Courses Teachers, 2015). Likewise, in "Vocational Qual- 
ifications for Students of Anatolian Imam Hatip High Schools"-published by the Ministry, acquiring the skills of duly Quran recitation and recognition of its content in general terms for students have been included (MoNE DGfRT IHHSs Student Qualifications, 2019).

There is a flow of Imam Hatip High Schools students into the Faculties of Theology/Islamic Sciences. It is clear that Imam Hatip High School graduates also prefer Faculties of Theology/Islamic Sciences, some of the graduates of these faculties serve as teachers at Imam Hatip High Schools. The quality of Quran instruction at both institutions affect each other positively or negatively. The graduates who have received good Quran education at Imam Hatip High Schools are more successful during their university and postgraduate lives at Faculties of Theology/Islamic Sciences and in religious services. However, the ones who have graduated from the faculties without having vocational competencies in Quran recitation can not be successful in the vocational field and they can not fulfill the expectations and the needs of the students and the society.

In order to be successful in teaching the Quran course, it is necessary to know and apply the special teaching methods and techniques of the skill of tilavet (recitation of Quran). In this context, the traditional and common teaching methods that come to the fore in the teaching of the lesson, the "seam", which means that a student learns by listening to his or her teacher, "arz" which means that the student reads and his or her teacher listens carefully (Pakdil, 2017, s. 30), and the eda which is implimentation of sema and arz together as a mixed method which teacher reads firstly and then the student repeats it (Y1lmaz, 2016, s. 54; Tetik, 1990, s. 240).

Balanced teaching of theoretical and practical training in tajwid education, making letter pronunciation training at certain intervals and making use of collective teaching with choral practice are the main traditional and common methods. Among the general teaching methods in teaching Quran are; taking into account the readiness of the students, teaching students gradually, using the exercise and repetition and the group working method, which are very important (Biceğez, 2017, s. 91-92, 96).

When these traditional and common methods are evaluated with their equivalents in educational sciences, sample reading correspond with the demonstration method of seam, the method of arz corresponds with the receiving feedback from the student and correcting; whereas eda corresponds with showing and getting feedback and correcting; showing a model of listening sample reading 
from course materiala corresponds with choral recitation and the formation of level groups which can be said that corresponds or is similar to the cluster study method (Aydın, 2010, s. 288-290; Aşıkoğlu, 2010, s. 553).

According to the survey, since 1924 until today, the determination of instructional methods and techniques regarding the curriculum/training programs for the Quran course taught in the Imam Hatip schools aimed to reveal the existing similarities and differences, evaluate the developments in the process and the reflections on practice.

\section{Method}

The document analysis method, one of the qualitative research designs, has been used in this study, which is the subject of chronological ordering of the issues related to the teaching methods and techniques in the Imam Hatip Schools, Imam Hatip High Schools and Anatolian Imam Hatip High Schools Qur'an Course Curriculum. The curriculum of the Quran course, the number of weekly course hours and the information about the teaching methods and techniques in these programs have been studied since 1924 until today.

\section{Findings and Comments}

The curriculum of the course of Quran that has been designed for the years of 1924-1933 is in the form of a curriculum rather than a teaching programme in which course contents are included. While the courses and the subjects are included in the curriculum; the objective, the acquisition and the assessment sections that are key elements for the programme are not included (Tunç, 2019, p.60-61). Though, some methods that would be applied during the courses are partially included in the curriculum. As for these methods are; at the first grade, each of the students would recite Quran in turn and meharic-i hurûf (place of articulation of Quran letters) would be considered important. The most important parts of Tajweed will be taught practically, description (ta'rifat) and practice (tatbikat) would be performed during Quran recitation; thus the students' tajweed mistakes would be corrected. The second grade will be devoted to exercise (ta' lim) and tajweed. At the third and the fourth grades, exercise (ta'lim) and practice (tatbikat) would be continued, manner (edâ) and sound (sadâ) would be deemed important. Together with short surahs; Amme, Tebâreke, Fath, Yasin and some important surahs and verses would be definitely memorized by the students (Döğen, 1992, p.103). 
Without including the subjects in details, apprehension of Quran recitation in accordance with Tajweed rules and- within possibility- memorization of surahs and wide texts as a whole in order to be recited during the salaat have been demanded in the curriculum of the course of Quran that has been designed for the years of 1951-1972 (MoNE, 1955). There is not any explanation about the instruction of the courses of Quran in the newly prepared draft curriculum.

There has not been any innovation concerning the teaching methods in the curriculum of Quran that has been designed for the years of 1972-1984; providing ear training, correcting the pronunciation mistakes, observance of progressivity principle in memorization, emphasizing the practice in tajweed instruction through traditional methods that were remarked in the former programme - was founded satisfying.

In the curriculum of Quran that has been designed for the years of 1984-1999, within the sections called Quran reading from the written texts and memorization - regarding the course's teaching methods; the teacher is supposed to make two-page sample reading (model reading) through demonstration and in the meanwhile, the students are supposed to be all ears (sema'/hearing) also, letting the students read these two pages (arz/submission) in composite order and ensuring the others to follow that process, returning to the beginning when the pages are over (repetition) and the instruction of other courses on Quran reading from the written texts in the same way - have been demanded during the lesson. In tajweed instruction, within the teaching process of the course, writing the examples of tajweed rules on the board and performing model reading, finding examples on the verses (to help students find them), carrying on the application till the consolidation is done (repetition), reading tajweed rules in due form within the sections which are read from the original text or which are recited and performing them until achieving a complete understanding by making statements at some points (takrir/explanation), correction of tajweed mistakes during the students' chants (by receiving feedback), and making the students apply the tajweed rules on the read verses (having to do this by demonstration).

In the curriculum of Quran that has been designed between the years of 19992008, application of sema' method (having students do by showing, model reading) through reading the surahs and verses that must be memorized- and benefiting from the related course material (showing model), achieving a complete understanding within the sections that would be memorized by pieces in chorus (presentation, having students do by showing) - have been requested from the teacher. In meaning teaching, conducting brainstorming technique, etc. 
Activities for deducing the values from the parts of which meanings would be read; employing the methods that would motivate the students, particularly the question-answer method have been stated, regarding the meanings of the verses. The importance of the repetition has been underlined in Quran teaching; -as the occasion arises- the reiterance of the former recitations (memorisations) and reminding the tajweed rules have been emphasized (repetition).

In Quran reading from the written text; keeping the interests of the students alive continuously in composite order, considering the individual differences in measurement and evaluation, and expressing the meanings of the recitations (explanation/takrir) have been stated (MoNE, 1999b).

In the "Activity Samples" and "Instructions" sections of the curriculum of Quran that has been applied in the years of 2008-2016, sema' (demonstration, model reading) arz (having them do by demonstration), eda (having them do by demonstration and correction via feedback), making them find out, question-answer, group work, group reading and instruction, takrir (explanation), imitation, problem solving, exampling, observation, individual work, brainstorming, didactic play, peer learning, case study, role playing, panel and small group discussion become prominent as teaching methods and techniques during the instruction process (MoNE, 2008a, 31-46; Aydın 2011a, p.281-294). From a program development point of view, this present situation is a positive development in terms of the influence of the new applications of methods and techniques of the course of Quran in the curriculum.

When the programme is analyzed which has been applied since 2016, it can be said that the methods and techniques of the course are generally included but it is not as rich as the former programme in regards to "activities". Hence, the methods and techniques that were broadly included within the curriculum - that was prepared in 2008 - under the titles of "Activity Examples", "Instructions", "Sample Activity Applications of Curriculum"; have been generally included in the curriculum that was prepared in 2016 under the titles of "Principles and Instructions on Application of Curriculum" section and "Instructions" on acquisitions section. But there is no big difference between the curriculum of Quran that has been applied since 2016 and the former curriculum, in terms of teaching methods and techniques. Hence, "The Method in Quran Teaching" section that was partially included in the curriculum -that had been prepared in 1984 and instructed till the year of 1999- has been involved in the programme as a seperate unit called "Basic Principles and Methods in Quran Teaching" at the level of the 10th grade. 


\section{Gonclusion and Recommendations}

There have been positive developments in applying special teaching methods and techniques in the curriculum/teaching programs of the Quran that has been prepared and put into practice in certain periods since 1924 for Imam Hatip Schools. It has been observed that especially in the programs prepared after 1984, more importance is given to the knowledge of method.

In the curriculum taught in 1924-1933, the methods of sema, arz, takrir (in the tajwid it is the clarification of the parts that are not clear enough and cannot be easily understood by the students.) and tekrar (repetition) were included. The curriculum taught between 1951-1965 did not include information about the teaching methods and techniques of the course, but only taught the Quran according to the rules of tajwid with the sema and arz method and some surahs were memorized. In the curriculum prepared in 1965, with some additions, the methods of sema, arz, eda and model showing were included. Changes were made on the same curriculum in 1972, and additionally, attention was drawn to learning by doing and experiencing.

The teaching methods and techniques of the Quran course were first included in the program prepared under the name of "teaching program" in 1984. In the curriculum, it has been requested to apply the methods and techniques of sema, arz, eda, showing models, takrir, tekrar (repetition), individual work, Socratic method. In the curriculum that was put into practice in 1999, methods and techniques of sema, arz, eda, model showing, choral work, takrir, tekrar, brainstorming, Socratic method, question-answer were included as methods and techniques in the teaching of the course.

It was seen that the program prepared in 2008 included methods and techniques in more detail compared to the previous years. In the program in question, sema, arz, eda, question-answer, cluster study, choral work, takrir, taklid (imitation), tekrar, problem solving, model showing, observation, Socratic method, role-playing, individual work, brainstorming, educational play, collaborative learning, small group discussion and panel methods and techniques were included. Although the curriculum implemented since 2016 did not contain the details of the previous program, it was seen that it contained adequate methods and techniques. The program included sema, arz, eda, model demonstration, takrir, tekrar, Socratic method, question and answer, brainstorming, small group discussion, taklit(imitation), problem solving, 
collaborative learning, cluster study and observation methods and techniques. The fact that the basic principles and methods of teaching the Quran were put as an independent unit can be considered as an important development for this program.

There have been positive developments in the teaching methods and techniques of the course. However, teachers' professional competence has an important place in realizing the program's objectives. It can be said that the main problem and the source of discussions about the quality of Quran teaching are directly related to the application of special teaching methods and techniques by qualified teachers rather than the curriculum and material. The need of teachers who have Kâri's (Who read the Quran according to its rules) and Mukrî's [A scholar of qiraah (reciting the Quran) who narrates (from mouth to mouth) from a master who received recitations with a sound and uninterrupted attribution] qualities in the teaching of the Quran, who know and apply special teaching methods, and who undergo a special education process in this field, is an issue that all Quran educators agree on.

This research is a study aimed at determining the teaching methods and techniques included in the teaching programs of the Quran course. The level of reflection on the methods, techniques and materials used in the current curriculum and in the textbooks in the application should be investigated. To realize the objectives put in the curriculum at a desired level and to provide Quran education according to the readiness and expectations of the students, further studies should be carried out on what new methods and techniques can be developed and how to apply them in addition to traditional and common methods. In Turkey, comparative academic research on the Qoran teaching methods and using of materials in other Islamic countries and Muslim communities should be carried out.

Etik Beyan / Ethical Statement: Bu çalışmanın hazırlanma sürecinde bilimsel ve etik ilkelere uyulduğu ve yararlanılan tüm çalışmaların kaynakçada belirtildiği beyan olunur. / It is declared that scientific and ethical principles have been followed while carrying out and writing this study and that all the sources used have been properly cited.

Finansman / Funding: Yazar, bu araştırmayı desteklemek için herhangi bir dış fon almadığını kabul eder. / The author acknowledges that he recevied no external funding in support of this research. 